\title{
Gracia y libre albedrío en san Agustín y en Lutero
}

\section{La tragedia de la incomprensión en el s. XVI y la hermenéutica de las culturas}

\section{INTRODUCCIÓN}

Todos los teólogos conocen la importancia radical que tuvo para Lutero y la Reforma la doctrina de la «justificación gratuita por la sola fe o gracia de Dios por Jesucristo", como un artículo de vida o muerte para la cristiandad: articulus stantis vel cadentis Ecclesiae ${ }^{1}$. Y esa misma importancia radical, aunque con nuevos matices, continúa en el diálogo ecuménico actual entre los luteranos y las demás confesiones cristianas, en especial con la Iglesia católica ${ }^{2}$.

Los más grandes ecumenistas actuales reconocen también con $\mathrm{Y}$. Congar que es preciso partir siempre de Lutero si se quiere hacer un verdadero ecumenismo con la Reforma. Sin embargo, la cuestión está en acercarse a Lutero con sus mismas categorías mentales, bíblicas en general, y no con las catego-

1. Cfr. P. Althaus, Die Theologie Martin Luthers, Gütersloh, ${ }^{5} 1980,195 \mathrm{ss} . ;$ W. (Ed. Weimar) 40 III, 335, 352; 39 I, 205; 25, 330; 31 I, 255; «doctrinae Ecclesiae caput» (De servo arb., W. 18, 649); si lograra que el Papa reconociera esa doctrina, iría a llevarlo en la silla gestatoria e incluso a besarle los pies: «Sed hoc quaerimus, ut stet gloria Dei et iustitia fidei illaesa conservetur, ut simus nos salvi et ipsi. Hoc impetrato, scilicet quod solus Deus ex mera gratia per Christum iustificet, non solum volumus Papam in manibus portare, imo etiam ei osculari pedes» (In Ep. S. Pauli ad Gal. Commentarius, a. 1531, 1535, W. 40 I, 181, 1. 11-13).

2. Cfr. E. Wolf, Die Rechtfertigungslehre als Mitte und Grenze reformatorischer Theologie, en Peregrinatio, Bd. II, München 1965; Rechtfertigung. Festschrift für Ernst Käsemann, hrsg. von J. Friedrich, W. Pöhlmann, P. Stuhlmacher, Tübingen-Göttingen 1976; Rechtfertigung im okumenischen Dialog. Dokumente und Einführung. Hrsg. von H. Meyer und G. Gassmann, Frankfurt a.M. 1987; el diálogo entre luteranos, evangélicos en general y católicos (107-248). 
rías, que él rechazó de plano, del aristotelismo de los escolásticos. Precisamente Lutero creyó descubrir en esas categorías, tan extrañas a la mentalidad semita, una nueva sombra de pelagianismo, del mismo modo que el padre de su Orden, san Agustín, la había descubierto y combatido en el siglo v en los pelagianos, imbuidos también de las categorías aristotélicas. El núcleo del pelagianismo, con su gran optimismo creacional, atribuía a Dios ciertamente la libertad otorgada al hombre en la creación misma; sin embargo, atribuían únicamente al hombre la posibilidad de «elegir entre el bien y el mal, entre pecar y no pecar» (libertas contrarietatis). Dios sabe desde toda la eternidad esa elección del hombre (praescientia), y según esto le otorgà, o no, su gracia externa de salvación (ley de Moisés, Jesucristo-Ejemplo): de este modo, Dios dependería en último término de la decisión del hombre para salvarlo, o no. Las diversas interpretaciones modernas que van apareciendo en torno al pelagianismo y a la doctrina de san Agustín no parecen haber atendido ni a las culturas o filosofías de donde proceden, ni siquiera a sus consecuencias de todo tipo para la espiritualidad cristiana ${ }^{3}$.

Me atrevo a afirmar que la confusión actual es muy parecida a la que cundió en el s. XVI entre los teólogos escolásticos, de tipo aristotélico como los pelagianos, y Lutero y sus seguidores, de mentalidad eminentemente bíblica y agustiniana, o dinámica, según veremos más adelante. Se trata ante todo de la noción misma de libertad y de la acción de Dios en el hombre, que en san Agustín y en Lutero, al igual que en el Evangelio y en san Pablo, se mueven en un plano de dialéctica vital o lucha interior entre la tendencia al bien y la tendencia al mal y al egoísmo; pero de tal modo que, para querer y hacer el bien, el hombre necesita ser atraído por Dios con el deseo de placer y delectación en su voluntad, mientras que el rechazo de la voluntad divina, el no, el pecado son de exclusiva cosecha humana. Todo se mueve en ellos en un plano experiencial y psicológico, como corresponde a la mentalidad dinámica bíblica y a la propia experiencia de la conversión.

3. A. Turrado, La antropología de san Agustín en la polémica antipelagiana. Su lectura después del Vaticano II, en "Obras Completas de san Agustín», t. XXXV, BAC, Madrid 1984. En este sentido, habría que matizar el substrato teológico y filosófico del pelagianismo (su aristotelismo y su noción de libertad y de gracia) mucho más de lo que aparece en F.G. Nuvolone-A. Solignac, Pélage et Pélagianisme, en «Dictionnaire de Spiritualité ascétique et mystique», t. XII, $2 .^{\circ}$ P., Paris 1986, col. 2889-2942. A. Solignac recuerda la noción aristotélica y estoica de libertad de los pelagianos, «la posibilidad de elegir entre el bien y el mal» (Lb., 2926), pero no la compara con la noción utópica del NT que les opone san Agustín. También admite con G. Greshake que la doctrina de ambos Testamentos es para los pelagianos «un estímulo interior» y no puramente externo (col. 2928s). Sin embargo, la falta en ellos del «diálogo de gracia» del NT y de san Agustín, y ese «hacer depender a Dios de la decisión futura del hombre» (núcleo central del pelagianismo) tiene muy graves consecuencias para la teología y la espiritualidad cristianas. 
Hay dos temas fundamentales que es preciso analizar con esmero para comprender mejor la tragedia de la incomprensión mutua en el s. XVI, semejante en parte a la del s. $\mathrm{V}$ en la polémica pelagiana: en primer lugar, que san Agustín y Lutero defienden una noción evangélica de libertad, y por lo mismo utópica, poniendo como modelo supremo de la misma al Padre celestial, que sólo puede querer y hacer el bien (Mt 5,48), él por naturaleza y los bienaventurados por gracia. En cambio, los pelagianos y en el s. XVI los escolásticos defendían la noción aristotélica y estoica del libre albedrío «como la posibilidad de elegir entre el bien y el mal, entre pecar y no pecar» (elección entre dos contrarios). En segundo lugar, en san Agustín y en Lutero, la gracia o ayuda de Dios para querer y hacer el bien se mueve en una perspectiva dialéctica de diálogo, pero con dos polos distintos: el diálogo de gracia o de ayuda divina parte siempre de Dios en virtud de la redención por Cristo y es una atracción, suavidad, caridad del Espíritu Santo, que nos convierte en árboles sanos que dan frutos sanos; en cambio, el hombre por sí mismo sólo puede decir no a la voluntad divina, y eso equivale a poder romper ese diálogo de gracia o a poder sólo pecar.

Será preciso analizar estos dos temas a la luz de la mentalidad dinámica semita, porque se siguen diciendo cosas muy extrañas sobre la doctrina de Lutero, e incluso los mismos profesores luteranos no dudan en afirmar que Lutero es para ellos «un verdadero acertijo o un enigma» (ein Rätsel): una especie de camaleón, que cambia de doctrina según las circunstancias; si bien, dice el profesor evangélico de la universidad de Erlangen, G. Müller, eso se debe a la lejanía para nosotros de las situaciones que Lutero tuvo que vivir ${ }^{4}$. Y, habría que añadir, por no poder ya captar el substrato cultural que servía de base a la doctrina de Lutero. Por eso, a pesar de la abundante bibliografía con ocasión de su jubileo en 1983, los autores que hacen balance del mismo se muestran bastante pesimistas en cuanto a los resultados. Según ellos, han predominado los estudios históricos sobre la vida y la época de Lutero, pero apenas ha habido progreso alguno en lo tocante a los temas fundamentales de su doctrina ${ }^{5}$.

4. G. MÚlLeR, Der fremde Luther, Die Last der Tradition im neuzeitlichen Protestantismus, en «Weder Ketzer noch heiliger. Luthers Bedeutung für den ökumenischen Dialog», Regensburg 1982, 93-122; ver p. 93.

5. Cfr. O.E. PESCH, Einführung, en «Lehren aus dem Luther-Jahr. Sein Ertrag für die Ökumene», O.H. Pesch (Hrsg.), Freiburg i. Br. 1984,8 (se refiere al pesimismo reinante en la reunión de la Academia católica de la diócesis de Frigurgo); Luther 83. Eine kritische Bilanz, C.P. Roepke (Hrsg.), München 1984 (art. de católicos y protestantes). Casi todos insisten en que muchas celebraciones de ese jubileo fueron motivadas, no por cuestiones en torno a la vida y a la doctrina de Lutero, sino por intereses ideológicos y comerciales, especialmente en la República Democrática Alemana (DDR); J.J. Alemany, Panorama bibliográfico del centenario luterano: Miscelánea Comillas 42(1984)79-101. 
Uno de los mejores conocedores actuales de la doctrina teológica de Lutero, Otto H. Pesch, ha podido experimentar en sus muchas conferencias en este jubileo la profunda ignorancia tanto de los católicos como de los luteranos sobre los temas centrales de su doctrina ${ }^{6}$. Y en cuanto al tema de la relación entre la gracia y el libre albedrío, fundamento de la doctrina de Lutero sobre la justificación, el mismo Pesch se limita a decir que en Lutero no desaparece el libre albedrío, porque también él exige al hombre su responsabilidad en la respuesta al don gratuito de la fe (Wort-Antwort), si bien la noción de diálogo de gracia atemoriza a los pastores luteranos que creen ver en ella una mengua de la gratuidad del don de la fe, y un oscurecimiento de esa «mística pasividad» de que habla a veces Lutero. De todos modos, la confusión en ese tema central continúa viva entre los fieles y los pastores de ambas confesiones ${ }^{7}$. Pero creo que el teólogo católico O.H. Pesch no analiza el substrato esencialmente bíblico y agustiniano de la dialéctica vital de Lutero en esa cuestión fundamental. Es muy estimable su postura abierta que contempla como católicamente válidas las dos grandes teorías sobre la justificación: la teología existencial de Lutero, que implica al que profesa la fe, frente a la de Tomás de Aquino, quien al objetivar con más vigor la acción de Dios en la naturaleza y en la historia, trata de reflexionar sobre ella de un modo sapiencial. Esa controversia clásica no sería ya, según Pesch, motivo de división en la Iglesia ${ }^{8}$.

Algunos autores, como el teólogo evangélico H.A. Oberman, ponen de relieve el posible influjo de san Agustín en Lutero, tanto directamente como a través de los teólogos medievales Pedro d'Ailly, Gabriel Biel o Gregorio de Rímini 9. Todos reconocen de algún modo esa herencia agustiniana en Lutero, pero la inmensa bibliografía actual no refleja la importancia decisiva de la mentalidad dinámica, de la dialéctica vital y de la noción evangélica utópica de libertad, por otra parte tan bíblicas y en especial tan paulinas, como única clave válida para comprender su doctrina. Hoy día sabemos ya con toda certeza que Lutero estudió cuidadosamente las obras antipelagianas de san Agustín, especialmente desde su comentario a la Carta a los Romanos (1515-16); de tal modo que en 1518 , en su prólogo a la Theologia teutsch, de autor descono-

También en los estudios posteriores al jubileo predomina la historia sobre la doctrina. Cfr. D.K. McKim, Current Theology. Recent Lutheran Studies: Theological Studies 48(1987)499-504.

6. O.E. PESCH, Gemeinden fragen nach Luther. Lehren für die systematische Theologie aus Vortragserfahrungen im Luther-Jahr, en «Lehren aus dem Luther-Jahr», 125-150:

7. O.E. PESCH, art. cit., 138-139.

8. O.E. PESCH, Hinführung zu Luther, Mainz 1982; Id., Gerechtfertigt aus Glauben. Luthers Frage an die Kirche, (Questiones Disputatae, 91), Freiburg-Basel-Wien 1982; G. Seebass, Ein Luther ohne Goldgrund. Stand und Aufgaben der. Lutherforschung am Ende eines Jubiläumsjahres», en «Lehren aus dem Luther-Jahr», 49-85; ver 66-69.

9. H.A. OBERMAN, Werden und Wertung der Reformation, Tübingen ${ }^{2} 1979,82-140$. 
cido, afirma expresamente: «No he hallado libro que me haya enseñado mejor lo que es Dios, Cristo, el hombre y todas las cosas, como la Biblia y Agustín» ${ }^{10}$.

Creo que es precisamente por no llegar al fondo de esa mentalidad dinámica y de esa dialéctica vital bíblicas por lo que Lutero sigue siendo un enigma para los mismos luteranos, y por lo mismo sólo un limitado número de autores católicos, a modo de excepción, como O.H. Pesch, D. Olivier y P. Manns, lo consideran como una figura notable de la propia tradición ${ }^{11}$. De hecho, en su último jubileo de 1983, se ha visto que las dificultades clásicas afloraban de nuevo sin remedio, y que muchos autores católicos han seguido defendiendo los mismos tópicos de siempre desde Erasmo, de que Lutero negaba totalmente el libre albedrío del hombre en el orden de la salvación en aras de la "pasividad ante el don de la fe» ${ }^{12}$, sin molestarse en captar el verdadero sentido de esas expresiones.

Ante tantos contrastes, es preciso recordar que Lutero trató siempre de realizar la reforma evangélica "desde dentro de la Iglesia», y que el mismo Juan Pablo II, en una carta dirigida al cardenal Johannes Willebrands, presidente del Secretariado para la Unión de los cristianos, le pide, entre otras cosas, que se llegue «por medio de una investigación sin prejuicios, movida sólo por la búsqueda de la verdad, a una imagen justa del Reformador, de toda la época de la Reforma y de las personas que estuvieron implicadas. La culpa debe ser reconocida alli donde se encuentre» ${ }^{13}$. Es la misma postura de búsqueda de la verdad que aparece en el Sínodo de la Iglesia Evangélica de Alemania y en las declaraciones de la Comisión conjunta Romano-Católica y Evangélico-Luterana con ocasión del jubileo de Lutero ${ }^{14}$.

10. W. 1,378. Cfr. A. Wernicke, Los Agustinos y la Reforma: Rev. Agustiniana 24(1983)321-340; G. CHANTRAINE, Erasme et Luther libre et serf arbitre, Paris-Namur 1981, $457-$ 459 (bibliogr. sobre el influjo de san Agustín en Lutero); G. PANI, Martin Lutero. Lezioni sulla lettera ai Romani (Römervorlesung 1515-1516), I riferimenti ad Agostino. La giustificazione. Roma 1983.

11. Cfr. G. SEEBASs, art. cir. en la nota 8, 49-85; ver p. 53.

12. Ver un compendio de esta postura clásica en J. BusQueTs, ¿Quién era Martín Lutero? Salamanca 1986. Compendia en gran parte los estudios de historiadores como J. Delumeau y R. García Villoslada; A. TRAPE, Lutero intérprete di S. Agostino sulla libertà e la grazia?, en «Agostino e Lutero. Il tormento por l'uomo" (Convegni di S. Spirito, 1), Palermo 1985, 11-19; G. Chantraine, o.c., en la n. 10. Habla en la introducción de la hermenéutica o distintos métodos de interpretar a Lutero (XXXVIIss.), pero, a pesar de la cita de E. Przywara, más tarde no atiende a la cultura semita y agustiniana sin la cual resulta ininteligible y contradictorio en extremo. $Y$. Congak̀, Martin Luther, sa vie, sa réforme, Paris 1983, etc. (1452).

13. Juan Pablo II, Carta al card. Willebrands (10 nov. 1983): Ecclesia, 19 nov. 1983, 12

14. H. Lowe, Das Jahr, das sich nach Martin Luther nannte. Eine kirchliche Bilanz der Gelegenheiten und Verlegenheiten, en «Lehren aus dem Luther-Jahr», Freiburg i. Br. 1984, 29-48; 
El gran historiador católico del concilio de Trento, Hubert Jedin, recordaba hace años la opinión del teólogo liberal Adolf von Harnack con respecto a la doctrina de Lutero sobre la gracia y el libre albedrío. Tal vez, según Harnack, no se hubiese desarrollado la Reforma si el decreto tridentino de la justificación hubiese sido elaborado por el concilio Lateranense V (1512-17) y hubiese sido asimilado por la Iglesia ${ }^{15}$. Sin embargo, no creo probable que Lutero hubiese aceptado ese decreto de Trento, tanto por el substrato doctrinal y la terminología aristotélico-tomista como por su falta de claridad bíblica en lo referente a la relación entre la gratuidad de la gracia y el libre albedrío, según lo demuestra su rechazo total de la doctrina y de las «contradicciones continuas» de Erasmo en una de sus obras predilectas, De servo arbitrio (a. 1525). Además, según nos lo advierte O.H. Pesch, no debemos caer en el absurdo de interpretar a Lutero (y habría que añadir: ni a san Pablo y a san Agustín) en función de las categorías fisicistas aristotélicas, cuando hablan de la acción divina y de la gracia en un marco totalmente distinto de los concursos e impulsos físicos del Dios, primer motor inmóvil, del aristotelismo y de la escolástica ${ }^{16}$. Son dos modos diversos de comprender la fenomenología de la conversión como un «proceso»; y la explicación existencial y dialéctica de san $\mathrm{Pa}-$ blo, san Agustín y Lutero es mucho más experiencial y más real que la exposición fisicista y estática de los escolásticos.

Todo esto nos indica que el único camino para llegar al fondo de la cuestión es la aplicación cuidadosa de la hermenéutica de las culturas, es decir, analizar con esmero las diversas culturas o filosofías que sirven de substrato a esas doctrinas enfrentadas y a su lenguaje. De este modo la doctrina de Lutero vuelve a ser una llamada a la «conciencia hermenéutica» (por usar la expresión de H.G. Gadamer), según lo indica la recomendación del mismo Juan Pablo II en la carta al cardenal Willebrands antes citada. Y esa hermenéutica, que implica muchas horas de penosa labor, implica también un serio análisis de ciertas interpretaciones de la sagrada Escritura, norma normans de la fe cristiana, que han podido adulterar en parte esa fe primitiva con adherencias espúreas de otras culturas como el helenismo. Al menos, de ese modo, podremos captar los diversos enfoques de la cuestión que nos ocupa y los diversos

H. Zeddies, Luthers unbequemes Jubiläum. Beobachtungen und Überlegungen zum Luther-Jahr aus dem DDR, Ib., 11-28.

15. H. JEDIN, Ist das Konzil von Trient ein Hindernis der Wiedervereinigung en «Kirche des Glaubens, Kirche der Geschichte», Herder, Freiburg-Basel-Wien, II, 1966, 540; A. von Harnack, Lehrbuch der Dogmengeschichte, 1931-19325, III, 711.

16. O.E. PESCH, Hinführung zu Luther, 176-188; Id., Frei sein aus Gnade. Theologische Anthropologie, Freiburg i. Br. 1983, 202ss; A. TuRrado, Sto. Tomás de Villanueva como teólogo: la herencia agustiniana entre el erasmismo y el luteranismo: Rev. Agustiniana 28 (1987) 399438; ver p. 422ss. 
lenguajes que, por falta de diálogo y de mutua comprensión, produjeron la gran desunión de la Iglesia de Occidente. No voy a exponer aquí los diversos puntos de esa hermenéutica, analizados no hace mucho en La antropología de san Agustín en la polémica antipelagiana (BAC, Madrid 1984, 15ss.), y que conducen a conclusiones clarificadoras y sumamente equilibradas.

II. RELACIÓN ENTRE LA GRACIA Y EL LIBRE ALBEDRÍO EN SAN AGUSTÍN Y EN LUTERO: MENTALIDAD DINÁMICA SEMITA DEL N.T. DiAlÉCTICA VITAL; NOCIÓN UTÓPICA EVANGÉLICA DE LIBERTAD; LA GRACIA COMO «ATRACCIÓN DELEITOSA» EN EL ESPÍRITU SANTO; EL NO O EL PECADO, EXCLUSIVO DEL HOMBRE

Antes de analizar estos puntos, es preciso recordar aquí a grandes rasgos la evolución profunda de la antropología teológica en estos años, especialmente a partir del Vaticano II. Es una evolución muy radical con respecto a algunos puntos de la antropología anterior, -no se olvide que se trata de antropología y no del credo-, y por lo mismo no debemos olvidarlos nunca al exponer la doctrina de san Agustín y de Lutero ${ }^{17}$.

Me refiero ante todo a la reinterpretación de una de las tradiciones míticas de los hebreos para tratar de explicar de algún modo el origen del mal y sobre todo el origen de la muerte en el mundo. Si bien en la Biblia predomina el mito de la envidia de los ángeles malos (y el Corán la recoge ampliamente de un apócrifo cristiano), el hecho es que debido a la dialéctica de san Pablo entre el Adán terreno y el Adán celeste, Cristo (Rom 5,12-21; 1Cor 15,45.56), en la teología patrística, en los concilios y en toda la teología cristiana predominó el mito del paraíso terrenal del Génesis (cc. 2-3). Tomaron como historia lo que era simplemente una catequesis simbólica hebrea para explicar que el mal y la muerte entraron en el mundo por el egoísmo y la desobediencia de los hombres y de las mujeres a Dios ( seréis iguales a Dios!). Hoy día, debido sin duda a la nueva hermenéutica de las culturas y de los géneros literarios (que implica la historia de las formas o método histórico crítico, la semiótica y lá filología), y debido también a la hipótesis científica de la evolución comúnmente admitida y al personalismo de las ciencias humanas y de la ética modernas, contemplamos en esos mitos una descripción de la realidad humana llena de contrastes personal y socialmente: esa dialéctica vital de la Biblia entre la tendencia al bien, al amor y la tendencia al mal, al egoísmo, que en la Biblia comienza con la narración del paraíso terrenal y termina con el hombre nuevo

17. A. TURRAdo, La antropología de san Agustín en la polémica antipelagiana. Su lectura después del Vaticano II, BAC, Madrid 1984, 6ss.; en el diálogo ecuménico, cfr. Rchtfertigung im ökumenischen Dialog, 150ss. 
y el hombre viejo de san Pablo y con el Cristo y el Anticristo de san Juan, es realmente la misma hybris o esquizofrenia de que hablan los griegos. Todos los seres espirituales creados, sometidos al tiempo y al espacio, tienden por el instinto de conservación a la propia consistencia, a constituirse en ídolos intocables, a ser dueños de su origen y de su fin, frente a Dios y frente a todos los demás. Esa tendencia a la autodivinización, experimentando de continuo que no somos dioses, produce en nosotros una lucha o un desorden (san Pablo la llama hamartía, o fuente de los pecados), que no cesará nunca en esta vida. De ahí que sean necesarias unas motivaciones muy fuertes para vivir el proceso siempre inacabado en esta vida de la justicia o de ir dando muerte en nosotros al egoísmo e ir renaciendo de continuo a la nueva vida de amor, como una vivencia pluriforme del misterio pascual de Cristo. Y digo «pluriforme», porque es del todo necesario superar con el Vaticano II la mentalidad tribal de la antropología anterior y partir de una auténtica teología de la creación. Los cánones antropológicos de Cartago, Orange y Trento sobre el pecado de origen reflejan esa antropología tribal (¡los pecados de los padres pasan a los hijos!) que les sirve como base para defender contra los pelagianos la necesidad de la gracia divina para la justificación y para la salvación, así como la mediación única de Cristo en el ámbito de las teologías de la redención entonces vigentes, también con matices tribales (redención como sacrificio y rescate, o como satisfacción de la deuda). Son imperfecciones que no afectan al credo o fe fundamental de la Iglesia, semejantes a la exageración tradicional, recogida por el concilio de Florencia: Extra Ecclesiam nulla salus. El Vaticano II, partiendo de una teología de la creación, habla de la salvación de todos los hombres de buena voluntad o de intención recta que implica siempre, como es obvio, el amor a Dios, si lo conocen o tal como lo conozcan y el amor al prójimo; es más, el concilio habla de que todos los hombres de buena voluntad, incluidos los ateos, participan del misterio pascual de Cristo «actuando en ellos la gracia de un modo invisible» (Gaudium et Spes, n. 22; ib., 12-17); Lumen Gent., n. 16).

Es, pues, preciso superar esa mentalidad tribal del pecado de origen como causa del mal en el mundo y partir de la teología de la creación, en la que se inicia la gran alianza de Dios con la humanidad entera por el hecho mismo de crear a hombres y mujeres capaces de esa rectitud de intención, si bien las llamadas de Dios a través de la conciencia o ley natural, sola o iluminada por las doctrinas religiosas más diversas y de un modo definitivo por la luz que es Cristo; son ya de hecho gracias o atracciones de Dios para que hagamos el bien (GS, 16-17); la nueva Alianza en Cristo es, pues, símbolo único y definitivo de la otra gran Alianza, es decir, del amor de Dios a la humanidad ${ }^{18}$. Por

18 Ver un compendio de esta cuestión y del cambio universalista de liberación integral del 
eso decía antes que la gracia de Dios es pluriforme, según la situación de las personas.

Una vez superada la doctrina tribal del pecado de origen como causa mítica del mal en el mundo, nos interesa más bien la descripción que hacen san Agustín y Lutero de la situación actual de la humanidad en orden a la salvación siguiendo la dialéctica vital de la Biblia y en especial de san Pablo. A este respecto bien podríamos decir con $\mathrm{R}$. Bultmann que la Biblia nos describe en forma mítica la existencia humana auténtica con sus anhelos, sus luchas y sus complejos; si bien para nosotros, bajo esos mitos nos han sido reveladas las grandes verdades de la fe como historia de salvación: creación, providencia, elección, pecado, encarnación, mediación, salvación, justicia. Las diversas teologías se fundan ya en las reflexiones sobre esas verdades reveladas partiendo de las diversas culturas según las épocas y lugares. De ahí la importancia que tiene la distinción entre el lenguaje de invocación, que expresa en fórmulas breves esas profesiones de fe (Jesús es el Kyrios, doxologías, el Credo), y el lenguaje de exposición o teologías que puede y debe variar según las culturas y las exigencias de la misión.

1. Fe y no racionalismo. Mentalidad dinámica utópica semita y sus consecuencias antropológicas, especialmente en san Agustín

Es conveniente tratar a la vez ambos temas para comprender mejor sus consecuencias antropológicas y su posible contribución al éxito del ecumenismo actual.

Ante todo debemos tener presente que tanto san Agustín como los demás santos Padres y los concilios de la Iglesia no tienen por sí mismos para Lutero una autoridad dogmática, sino únicamente una autoridad testimonial en cuanto sean intérpretes fieles de la sagrada Escritura. Esto lo repite él con insistencia durante toda su vida, y de hecho la praxis de los santos Padres y de los concilios ha sido siempre la de interpretar y defender la doctrina de la Escritura según las circunstancias de tiempo y lugar. En cuanto al «libre examen» atribuido a Lutero sin más, no deja de ser un tópico muy extraño de algunọs autorês católicos, puesto que él propone siempre las profesiones de fe del Credo y la gratuidad de la gracia como base inconmovible de toda inter-

\footnotetext{
hombre frente a las teologías clásicas y «tribales» de la redención en A. Turrado, La antropología de san Agustín, 148ss.; C. MAYER, Zum Wandel des chöpfungstheologischen Denkens in der katholischen Dogmatik: ThQ 158 (1978) 233ss.; Cathéchèse, n. 106, Jan. 1987 (todo el fascículo sobre la teología de la creación).- Para una visión de la teología actual sobre el pecado de origen, cfr. A. de Villalmonte, El pecado original. Veinticinco años de controversia: 1950-1975, Salamanca 1978; creo que se sitúan ya fuera de toda hermenéutica razonable obras como las de A.-M. Dubarle, Le péché originel. Perspectives théologiques, Paris 1983.
} 
pretación bíblica. Bastaría para convencerse de ello leer atentamente sus dos catecismos, otra de sus obras preferidas durante toda su vida.

Para descubrir el influjo de san Agustín en Lutero no basta, como se ha hecho con frecuencia, atender a las citas explícitas que él hace de las obras de san Agustín, en especial de las obras antipelagianas ${ }^{19}$. Lo cita con bastante frecuencia, pero en estos temas fundamentales el influjo de san Agustín en Lutero es mucho más profundo de lo que aparece en las citas. Se trata más bien de unos presupuestos doctrinales y metodológicos, presentes en toda su obra, junto con la descripción de su experiencia personal en lo referente a la relación entre el Padre del perdón y de la misericordia, tal como se nos manifestó en Jesucristo, y el hombre sometido a la lucha interna y externa, es decir, sometido a la dialéctica vital que san Pablo nos describió en todo su vigor.

Entre esos presupuestos comunes se pueden señalar: a) el rechazo total del racionalismo o de la razón (filosofía) que se opone o trata de imponerse a la fe; y b) el substrato de la mentalidad semita, dinámica y funcional, muy diversa del aristotelismo, esencialista y estático, y en el caso de Lutero, del aristotelismo-tomista de los escolásticos. Tal vez una breve exposición de estos puntos nos haga comprender mejor la tragedia del s. XVI y sus consecuencia hasta nuestros días.

\section{a) Fides quaerens intellectum}

La fe que busca ser mejor comprendida por todos los medios válidos que le ofrece la razón es la base de la metodología teológica de san Agustín. De este modo, la razón acepta el mensaje de Cristo porque responde a sus interrogantes más profundos (por lo tanto no es fideísmo, ya que los interrogantes parten del hombre mismo), y a su vez colabora a su mayor inteligencia por una mayor profundización de las analogías culturales en que esa fe nos fue transmitida (analogía fidei).

Agustín encontró al comienzo de su conversión muchos y grandes valores en el espiritualismo platónico y una gran ayuda para explicar de algún modo la creación del mundo únicamente por Dios contra los maniqueos y su dualismo creacional. Sin embargo, también es cierto que muy pronto comenzó a descubrir sus inmensas lagunas, según nos lo confirma en sus Confesiones y en La Ciudad de Dios. Su postura se fue radicalizando más y más en sus obras contra los pelagianos, de mentalidad aristotélica, precisamente porque, en

19. A. HAMEL, Der junge Luther und Augustin, 2 vol., Gütersloh 1934-35; W. von Löwenich, Von Augustin zu Luther. Beiträge zur Kirchengeschichte, Witten 1959. L. Grane, Divus Paulus et S. Augustinus, interpres eius fidelissimus. Über Luthers Verhältnis zu Augustin, en «Festschrift für Ernst Fuchs», hrsg. von G. Ebeling, E. Jüngel, G. Schunack, Tübingen 1973, 133-146, etc. 
opinión de san Agustín, anteponían la ética natural de Aristóteles y de Platón a la ética del Evangelio, destruyendo así la gratuidad de la gracia divina ${ }^{20}$. Por eso le dice con frecuencia a Julián de Eclana que acepte la doctrina de los grandes santos de la Iglesia, cuyo único doctor es Jesucristo, y que abandone a Polemo, a Platón y a Aristóteles y sus categorías; que la filosofía cristiana es la única verdadera, puesto que en ella está el amor de la sabiduría y la doctrina de Cristo ${ }^{21}$. Por eso, fiel a su principio metodológico, Agustín usará únicamente ciertos principios ya cristianizados del neoplatonismo, según veremos, para exponer y defender la fe cristiana.

Este mismo método de rechazar la razón o la filosofía que trata de imponer su ley a la fe es aún mucho más plástico en Lutero al enfrentarse con el aristotelismo de los escolásticos y, en su opinión, con un neopelagianismo evidente y destructor de la gratuidad de la gracia divina. Ese rechazo del aristotelismo de los escolásticos, y en especial bajo el aspecto ético, es una constante muy marcada durante toda su vida, ya algunos años antes del comienzo de su reforma ${ }^{22}$. Cambió en la universidad de Wittenberg los programas de la teología escolástica por la teología bíblica y patrística, en especial san Agustín, llegando a proponer para la promoción del agustino Franz Günther una serie de tesis con el título general: Tesis contra la teología escolástica ${ }^{23}$. Rechaza esa filosofía y teología, «que él tuvo que soportar también durante más de doce años», por ser racionalista, porque no ayuda a mejorar el entendimiento, el afecto ni las costumbres con sus discusiones inútiles ${ }^{24}$. Llama a

20. A. TuRrado, La antropología de san Agustín en la polémica antipelagiana. Su lectura después del Vaticano II, 48ss.; F.-J. ThONNARD, L'aristotelisme de Julien d'Éclane et saint Augustin: REtAUG. 11 (1965) 296-304; N. CIPRIANI, Echi antiapollinaristici e aristotelismo nella polemica di Giuliano d'Eclano: Augustinianum 21(1981)371-389; G. BONNET, Éthique et foi chrétienne dans la pensée de saint Augustin, en «Recherches Augustiniennes», 12, Paris 1977, 46-104.

21. C. Jul. I, 4,12; 10,37; III, 6,13; IV, 14,72; V, 14,51; Op. imp. c. Jul. II, 51; 166; V, 2324; VI, 18,53-57; 20,64, etc.

22. M. BRECHT, Martin Luther. Sein Weg zur Reformation 1484-1521, Stuttgart ${ }^{2} 1983$, 170s.; W. Eckermann, Theologie gegen Philosophie? Anfragen an Luther, en «Martin Luther. Annährungen und Anfragen». Hrsg. von W. Eckermann und E. Papp. Universität Osnabrück, Abteilung Vechta, 1985, 9-24.

23. Disputatio contra scholasticam theologiam (1517): W. 1,221-228. «Breviter, totus Aristoteles ad theologiam est tenebrae ad lucem» (Ib. n. 50, W 1,222); Sermo: Die conversionis Pauli (1517): W. 1,126-128; Actà Fr. Martini Luther Augustiniani apud D. Legatum Apostolicum Augustae (1518): W. 2,6-22; ver p. 17 contra la teología tomista.

24. Responsio Lutheriana ad condemnationem doctrinalem per Magistros nostros Lovanienses et Colonienses factam (1520): W. 6,181-195; Lutero se opone a la definición filosófica del hombre como «animal racional» (de Aristóteles y de la escolástica), porque no tiene en cuenta ảl hombre real, en pecado; por eso le opone la definición teológica o del «hombre en cuanto ha de ser justificado por la fe, justificandus fide. Cfr. G. Ebeling, Lutherstudien. Bd. II. Disputatio de homine, 1Teil, Tübingen 1977. Lutero da un nuevo sentido, relacional y dinámico, a los términos persona y conscientia; su antropología no se funda en el esquema tradicional de las potencias del 
Aristóteles peste y chivo, ángeles caídos del cielo a los que aprobaron y propagaron su filosofía racionalista, ruina de la cristiandad ${ }^{25}$.

Frente a esa cierta ilusión racionalista de los escolásticos de poder llegar por la sola luz de la razón al conocimiento del Dios de los cristianos, Lutero insiste, como lo hiciera ya san Agustín y muchos teólogos católicos actuales, en que al Dios del perdón y de la misericordia, al Dios-Amor que salva, sólo podemos llegar por Jesucristo, y éste muerto en la cruz y resucitado ${ }^{26}$. De todos modos, Lutero dirige sus dardos en especial contra la ética naturalista de Aristóteles y de sus secuaces, los escolásticos, porque ve en eso la destrucción total de la gratuidad de la gracia divina, tal como nos la presenta el Nuevo Testamento, y de un modo especial san Juan y san Pablo ${ }^{27}$.

Junto a esta característica común a san Agustín y a Lutero, aunque con sus matices especiales, que sólo admite la filosofía o la razón al servicio de la fe y de la teología (ancilla theologiae), es preciso atender al substrato semita de sus teologías sobre la gracia y la libertad.

b) La mentalidad semita, dinámica, funcional y utópica de la Biblia y sus consecuencias antropológicas

Ya he analizado esta cuestión fundamental al exponer recientemente la antropología de san Agustín en sus obras antipelagianas ${ }^{28}$. Creo que es una perspectiva esencial para comprender sus categorías doctrinales y no caer en la ilusión de atribuirle un sinfín de contradicciones. La hermenéutica moderna de las culturas, fruto de las ciencias del lenguaje, según apunté antes, ha movi-

alma, de un hombre neutro, sino en las fuerzas del hombre concreto (Daseinsmächte), con su impotencia en orden a sí mismo y a la definición de sí mismo. De ahí la necesidad de la revelación y de la fe para comprenderse. Cfr. G. Ebeling, Lutherstudien. Bd. II. Disputatio de homine. 2. Teil. Die philosophische Definition des Menschen. Kommentar zu These 1-19, Tübingen 1983, 263ss., 453ss.

25. Ad librum eximii Magistri nostri Magistri Ambrosii Catharini, defensoris Silvestri Prieratis, responsio (1521): W. 7, 698ss.; Disputatio de homine (1536): W. 39 I, 174-180; Vorlesungen über 1. Mose (1535-1545): W. 42,346ss., crítica a Escoto, el cual decía que el hombre «ex puris naturalibus possit diligere Deum super omnia», y critica también las alabanzas de Erasmo a Sócrates, etc.; Ib., W. 44, 771-776, 807-810, 817-824, etc.

26. Cfr. P. Althaus, Die Theologie Martin Luthers, 27ss.; Vorlesungen über 1. Mose: W. 44,591 ss. Al combatir el arrianismo, los errores contra la Eucaristía (Sacramentarios) y a los anabaptistas, dice: «Sed in theologia tantum est audiendum et credendum et statuendum in corde: Deus est verax, quantuncumque rationi videantur absurda, quae Deus in verbo suo dicit» (Ib, 593). Lutero no podía prever entonces que precisamente del seno del luteranismo iba a surgir la Ilustración o negación radical de todo misterio, y en teología, el liberalismo o filosofización de toda fe religiosa!

27. De servo arbitrio: W. 18, 606-706; Carta a Spalatin: W. Brw., 1, 219.

28. A. Turrado, La antropología de san Agustín, 72ss. 
do a los mejores exégetas actuales a analizar a fondo la cultura semita para poder comprender la sagrada Escritura ${ }^{29}$.

Para nuestro propósito, lo más importante de la cultura semita está en su noción dinámica y funcional del ser. El verbo hebreo hayah expresa siempre el ser-en-acción, como actuando, viviendo y haciéndose. Para los semitas, ser y acción no son dos conceptos opuestos, sino inseparables e integrados, mientras que para los griegos, en especial para los aristotélicos, la acción es un accidente pasajero frente a la naturaleza o substancia permanente. De ahí que, según Boman, es preciso recurrir a las analogías psicológicas del alma humana para captar el sentido del ser-en-acción de los semitas. Ser-en-acción que expresa ante todo al Dios creador y providente, siempre presente en la historia y en la creación, y a la persona humana en devenir constante en esa historia que va hacia adelante a su plenitud. Esta noción dinámica del ser hace que los hebreos apenas puedan expresar sus ideas mediante términos universales, y mucho menos, como dice G. von Rad, dentro de un sistema abstracto organizado. Necesitan para ello términos concretos, funciones y géneros literarios más plásticos, como la poesía, la saga, la parábola, la profecía, y en general la «metáfora viva», según la expresión de Paul Ricoeur.

Por eso los semitas tienen una teología de manifestación o epifanía, es decir, que hablan de las cosas y de los sucesos como si éstos comenzaran a existir cuando ellos los perciben o experimentan. No es éste el lugar apropiado para extendernos en la descripción de las trágicas consecuencias que ha traído para algunas cristologías actuales el olvido de esa teología de manifestación o epifanía semita cuando analizan la primera cristología de los Hechos (cc. 2-3) en un contexto esencialista griego, a pesar de todas sus protestas en contrario, negando la eternidad y por lo mismo la divinidad real de Jesucristo, como si hubiera comenzado a ser Kyrios y Mesías en la resurrección, es decir cuando los apóstoles percibieron quién era realmente su Maestro (Hch 2,36) ${ }^{30}$. Los grandes concilios trinitario-cristológicos de la Iglesia supieron traducir de verdad la mentalidad semita dinámica y de epifanía a la mentalidad esencialista griega sin desvirtuar su verdadero contenido de fe, tal como la profesamos en el credo o Charta magna de todas las confesiones propiamente cristianas.

Esa mentalidad dinámica bíblica y la teología de manifestación son tam-

29. Cfr. T. Boman, Hebrew Thought Compared with Greek, London 1960; J.A.T. RoBINSON, El cuerpo, Barcelona 1968; E. Wolf, Antropología del Antiguo Testamento, Salamanca 1975; H. MúHLEN, El Espíritu Santo en la Iglesia, Salamanca 1974, 114ss.; G.E. WRIGHT, El Dios que actúa, Teología bíblica como narración, Madrid 1974; G. vON RAD, Sabiduría en Israel, Madrid $1985,27$.

30. A. TURRADo, Reflexiones en torno al «caso Hans Küng» y a sus consecuencias: Rev. Esp. de Teol., 39/40 (1979/80) 391-420; y en Rev. Agustin. de Espiritualidad 20(1979) 291-330. 
bién esenciales para comprender la doctrina de san Agustín y de Lutero sobre la relación entre la gratuidad de la gracia y la libertad humana. Además, a esto hay que añadir el carácter esencialmente utópico y dialéctico-vital de la mentalidad hebrea. Según indiqué antes, desde la lucha entre el bien y el mal del Génesis en la persona y en la sociedad hasta la lucha entre el hombre viejo y el hombre nuevo de san Pablo y del Cristo y del Anticristo de san Juan, toda la historia de salvación de la Biblia se desarrolla en medio de esa dialéctica vital o lucha interior y exterior, así como con la esperanza firme en el triunfo definitivo del bien sobre el mal (utopía). Y esa vida de lucha y de esperanza, descrita sobre todo por san Pablo en su dimensión personal y comunitaria, produce una dialéctica vital o tensión continuada durante toda la vida terrena que lleva a los semitas a proponer como modelo al ejemplar supremo de bondad y de misericordia, y sobre todo de amor y autodonación total en su Hijo: sed perfectos como vuestro Padre celestial es perfecto (Mt 5,48); y otras expresiones semejantes: Amaos unos a otros como yo os he amado; que todos sean uno como yo en ti y tú en mí; el amor va expulsando el temor, etc. (Jn 15,12; $17,21 ; 1 \mathrm{Jn}, 4,18)$. Ser-en-acción, teología de epifanía o manifestación, dialéctica vital y utopía, son conceptos hebreos que están siempre presentes en la teología de san Agustín y de Lutero, sin los cuales parece su doctrina, como la de san Pablo, un laberinto de contradicciones.

c) Mentalidad dinámica bíblica. Neoplatonismo cristianizado. Noción de libertad evangélica y la gracia como «atracción deleitosa» por el Espí'ritu Santo, según san Agustín

Junto a la mentalidad bíblica antes mencionada es necesario tener presente en la doctrina de san Agustín el neoplatonismo ya cristianizado por Orígenes y por san Ambrosio, en especial para explicar la obra de la creación.

El influjo de Platón y de Plotino en san Agustín es bastante complejo, si bien en él está siempre condicionado por la doctrina de la Biblia a partir ya del tema central de las ideas ejemplares ${ }^{31}$. Éstas no son ya las ideas subsistentes en sí mismas del platonismo (logoi), sino que se identifican realmente con Dios mismo, Bien sumo, del cual participan los seres en diverso grado sus perfecciones ${ }^{32}$. Esta teoría neoplatónica de la participación cristianizada implica en sí las nociones de ejemplaridad, eficiencia y presencia de Dios en la

31. A. TuRrado, Dios en el hombre, BAC, Madrid 1971, 80ss.; Id., La antropología de san Agustín, BAC 1984, 73ss.; C.P. MAYER, Die Zeichen in der geistigen Entwicklung und in der Theologie des jungen Augustinus, Würzburg 1969, 127ss., 234ss.; Neoplatonisme and Christian Thought, ed. by D.J.O'Meara, Norfolk (Virginia) 1981; J. Pegueroles, San Agustín. Un platonismo cristiano, Barcelona 1985.

32. De div. quaest. 83, q. 46; A. Turrado, La antropología de san Agustín 75ss. 
creación, y sirvió a Agustín para combatir a los maniqueos en cuyas filas había militado él durante unos nueve años de su juventud. El mal no procede, les dice Agustín, del principio eterno del mal o materia (Hylê) en lucha continua con el principio eterno del bien, Dios, del cual proceden los espíritus encarcelados en los cuerpos (platonismo); sino que el mal es una carencia de bien allí en donde debería estar. Por lo tanto el mal no es nada creado por Dios, el creador único de todas las cosas. Pero Agustín enfoca esta noción metafísica del mal hacia la vida moral o la ética de los hombres, puesto que los maniqueos, y él mismo cuando lo era en su juventud, atribuían todo lo malo que hacían a «una cierta naturaleza que existe en nosotros» ${ }^{33}$.

San Agustín plantea todas las cuestiones antropológicas en el marco de una mentalidad dinámica y unitaria del hombre, de tal modo que, a pesar de todas las apariencias lingüísticas, no se ha de buscar en él la psicología racional de Aristóteles con las tres potencias del alma (memoria, inteligencia y voluntad) realmente distintas entre sí y realmente distintas del alma. En san Agustín se trata de un dinamismo espiritual unitario con diversos aspectos inseparables y siempre en acción (recordarse, entenderse y amarse: mens, notitia, amor o dilectio), imagen y semejanza dinámica de la intercomunión tripersonal Divina, a la cual debe ordenarse o asemejarse más y más por la caridad o amor al Creador y a sus cristuras: es el ordo amoris, reflejo fiel del mandato evangélico del amor a Dios, y al prójimo como a uno mismo; lo cual, dice san Agustín, sólo será posible cuando te ames a ti mismo sin egoísmo, como criatura de Dios ${ }^{34}$.

Según esto, san Agustín insiste en que la vida real de la humanidad, tal como es y como la describe la Biblia y en especial san Pablo, se desarrolla en medio de esa dialéctica vital o lucha personal y social entre el bien y el mal, predominando la soberbia y el egoísmo de donde proceden todos los demás pecados e injusticias. Aun prescindiendo del pecado de origen como causa de esa situación (es preciso repetirlo sin cesar; si bien no fue un invento suyo, como dice él mismo a Julián de Eclana, sino que se limitó a tratar de explicar su transmisión por la generación con la concupiscencia a partir del 418, en el De nuptiis et concupiscentia), su visión neoplatónica cristianizada de la creación como participación de perfecciones le lleva a constatar que nuestro libre albe-

33. Confes. V, 10,18; De lib. arb. I, 2,4; amplia exposición en C. MAYER, Die Zeichen in der geistigen Entwicklung und in der Theologie Augustinins, II. Teil: Die antimanichäische Epoche, Würzburg 1974; C. GARCía LóPEz, Bases para una interpretación del maniqueísmo: Pensamiento 43(1987)463-477.

34. A.Turrado, o.c., 76ss; L. Cilleruelo, Teología espiritual. I. Ordo amoris, Valladolid 1976. «Sic enim condita est mens humana, ut nunquam sui non meminerit, nunquam se non intelligat, nunquam se non diligat» (De Trin., XIV, 14,18). 
drío, en el orden de la salvación, no puede actuar por sí solo sin la ayuda de la gracia divina; que en nuestro dinamismo espiritual unitario hay como una oquedad viva, una carencia de fuerza o virtud para querer y hacer el bien, carencia que debería estar ahí y no está por la debilidad, la ignorancia y la concupiscencia desordenada que nos invaden. De ahí la falta continua de la caridad debida en todo lo que hacemos (ideal o utopía evangélica), que explica la expresión de san Juan de que todos somos pecadores (1Jn 1,8ss). Es la noción de pecado que san Agustín desarrolla ampliamente en su obra Sobre la naturaleza y la gracia.

Para la mentalidad dinámica semita (ser-en-acción) y su consiguiente teología de manifestación o epifanía, que habla de las cosas cuando las percibe, es obvio que en el orden de la salvación el libre albedrío está ahí, pero es como si no existiera, puesto que no se manifiesta actuando. Por eso necesita ser robustecido, atraído y sanado por la gracia de Dios mediante Jesucristo y por la caridad del Espíritu Santo que nos ha sido dado (Rom 5,5). Es muy importante notar que esa gracia de que habla san Agustín, a pesar de sus divisiones posibles en el proceso de la conversión, no dice relación alguna a los concursos o impulsos fisicistas del aristotelismo de los escolásticos, sino que es de tipo psicológico, conforme al modo experiencial de actuar de los hombres, es decir, delectación en el bien, vigor, fuerza, suavidad, persuasión, caridad del Espíritu Santo ${ }^{35}$. Es un diálogo deleitoso, a modo de enamoramiento, que encuentra su placer en el cumplimiento de la voluntad de Dios o amor social a Dios y al prójimo en seguimiento de Cristo, y que hace posible y dulcemente inevitable la respuesta filial del hombre a la llamada que viene siempre de parte de Dios.

Sin embargo, aquí, en ese diálogo deleitoso, dulce e inevitable de gracia, que vivifica nuestra libertad debilitada para querer y hacer el bien (carencia de fuerza o vigor, por la dialéctica vital o lucha interior y exterior) puede aparecer con fuerza proporcionalmente opuesta a nuestra debilidad el aspecto negativo de nuestra libertad, el No a Dios en nuestro egoísmo: el pecado en cuanto desorden y aversión a Dios, que es lo único exclusivamente nuestro y lo único que puede por sí solo nuestro libre albedrío, cerrado de raíz al diálogo deleitoso de gracia. Este aspecto negativo de nuestro dinamismo volitivo no es para Agustín, como no lo es para san Pablo, una libertad verdadera o evangélica, sino más bien la expresión de nuestra miseria y lucha interior, la ruptura de la utopía evangélica de llegar a poder elegir sólo el bien como nuestro Padre celestial y la ausencia de esperanza en el triunfo final del bien sobre el mal.

De nuevo es preciso recordar que, para los pelagianos, sólo valía la defi-

35. A. Túrado, o.c., 99ss. La gracia como diálogo deleitoso (116ss). 
nición de libertad del aristotelismo y del estoicismo moral de Séneca y Cicerón, «como la posibilidad de elegir entre el bien y el mal, entre pecar y no pecar» (libertad de contrariedad). Es el caballo de batalla de la polémica pelagiana, porque con esa definición extraevangélica no hay ya cabida para la ayuda directa, concreta y gratuita de la gracia divina, se hace depender a Dios de las decisiones futuras del hombre pre-sabidas por él desde la eternidad y se desvirtúa el sentido de la oración que Cristo nos enseñó: No nos dejes caer en tentación y líbranos del mal. Agustín insiste en la única noción realmente evangélica de libertad, que es tratar de llegar a la utopía «de no poder elegir más que el bien, como nuestro Padre celestial (Mt 5,48) por naturaleza y los bienaventurados por gracia». De lo contrario nuestro Padre celestial, que sólo puede elegir el bien, no sería realmente libre ${ }^{36}$. Esa utopía se va logrando por un proceso siempre inacabado en esta vida por la guía y la suavidad del Espíritu Santo, fuente única de libertad evangélica (2Cor 3,16-17), el cual hace que nos deleite o atraiga por placer el bien y no el mal, sacándonos por la caridad de la esclavitud del pecado ${ }^{37}$. Es la gracia de Dios por Cristo en el Espíritu que nos atrae hacia el bien inevitablemente, pero no por coacción (necessario, non coacte), de un modo semejante al enamoramiento de las parejas humanas que es a la vez lo más libre y lo más inevitable cuando es verdadero. El decir no, el cerrarse a ese diálogo de gracia, el pecado, no pertenece al ámbito de la verdadera libertad y es obra exclusiva del hombre ${ }^{38}$. Por eso san Agustín repetirá sin cesar que «nuestros méritos son realmente dones de Dios», puesto que sin su ayuda no podríamos querer y hacer el bien, sino sólo pecar ${ }^{39}$. El que vea en esa pos-

36. Es el tema constante de san Agustín en su polémica con los pelagianos, en especial con Julián de Eclana: Op. imp. c. Jul., I, 89ss. «Si liberum non est, nisi quod duo potest velle, id est, et bonum et malum: liber Deus non est, qui malum non potest velle» (Ib., I, 99). A. TuRRADo, o.c., 113ss.; Id., La utopía y la dialéctica vital de la Biblia como característica esencial de la mentalidad de san Agustín, en «Homo Spiritalis», Festgabe für Luc Verheijen OSA, hrsg. von C. Mayer, Würzburg 1987, 76-99; y en «Estudio Agustiniano» 21(1986)451-473.

37. Hic autem Spiritus Dei, cuius dono iustificamur, quo fit in nobis ut non peccare delectet, ubi libertas est; sicut praeter hunc Spiritum peccare delectat, ubi servitus est» (De spir. et litt. 16,28); Ib., 30,5; De corrept. et gra. 12,33; In Io, tr. 41,8-9; S. 161,9,9; S. 156, 13, 14; In Ps. 138, 13 , etc.

38. Ex quo autem homo incipit uti voluntatis arbitrio, et peccare et non peccare potest: sed alterum horum non facit, nisi adiutus ab eo qui dixit, Sine me nihil potestis facere (Jo 15,5): alterum vero propria voluntate, sive a se ipso, sive ab alio deceptore seductus, vel peccato sicut servus addictus» (Op. imp. c. Jul. I, 98); Ib., V, 38; 54, 60; A. TurRado, o.c., 116ss; M. HuFTIER, Libre arbitre, liberté et péché chez saint Augustin, Louvain 1966; J.P. BuRns, The Development of Augustine's Doctrine of Operative Grace, Paris 1980.

39. Da a Dios lo que es suyo, es decir, date a ti mismo que eres su imagen. «Si de tuo retribuis, peccatum retribuis. Omnia enim quae habes, ab illo habes: tuum peccatum solum habes» (In Ps. 102,4); In Ps 142,5; De lib. arb. III, 1,2; 17,47; Retract. I, 13, 5; De pecc. mer. et rem. II, 4,4, etc. 
tura un pesimismo humanista ( $i$ si se prescinde del pecado de origen, presente en toda la teología cristiana durante tantos siglos!), debería pensar muy seriamente en la realidad del egoísmo y de la injusticia humana a través de la historia y en sí mismo, y captar el sentido profundo de la oración humilde y confia$d a$, expresada sobre todo en el Padrenuestro, que Agustín cita de continuo en contra del naturalismo pelagiano, así como la confianza total en el único Mediador entre Dios y los hombres, Jesucristo ${ }^{40}$. Por eso en uno de sus sermones exclama: «Cuando oramos, todos somos mendigos de Dios, omnes quando oramus mendici Dei sumus ${ }^{41}$. Fue también la última frase que dejó escrita Lutero antes de su muerte, y que propone con frecuencia como la única postura evangélica de todo cristiano.

Esa dialéctica viva y dialogal, con esos matices bíblicos y neoplatónicos, es esencial en la mentalidad filosófico-teológica de san Agustín, tanto en la búsqueda de la verdad y de la felicidad plenas como en la concepción de la vida cristiana como un diálogo humilde y confiado en la ayuda de la gracia, en las promesas de Dios al que ora y en el seguimiento de Cristo, modelo supremo de bondad y de amor que atrae a llevar la cruz de cada día y a amar sin medida ${ }^{42}$.

Hay que sacudir la pereza ancestral que producen ciertos esquemas absolutizados, como los del aristotelismo escolástico, para entender a los grandes genios del cristianismo y para volver más y más a la vida evangélica purificada de influencias espúreas. San Agustín ha sido interpretado en general mediante las categorías de ese aristotelismo escolástico, totalmente extraño y hasta rechazado duramente por él, y de ese modo se cerró el paso a una recta inteligencia de su doctrina y a la vivencia de esas utopías evangélicas que tanto significan para él, incluso en cuanto a la utopía política de su Ciudad de Dios. El «enigma» de Lutero, según los mismos luteranos, se debe también en mi opinión a la falta de un análisis serio de su herencia agustiniana, ciertamente unida a veces a otros matices especiales de su época, así como a su mentalidad utópica bíblica y al rechazo de la antropología y de la ética de Aristóteles y secuaces.

40. A. Turrado, o.c., 146ss.

41. S. 83,2 .

42. R. Berlinger, Augustins dialogische Metaphysik, Frankfurt a.M. 1962; J. PePIN, Saint Augustin et la dialectique, Villanova (USA) 1976; A. TurRADo, o.c., 128ss. 
2. La doctrina de Lutero en el marco de la mentalidad bíblica y agustiniana: relación gracia y libertad; la libertad evangélica y el No exclusivo del hombre; la gracia como «atracción deleitosa» por el Espíritu Santo

No voy a exponer aquí ampliamente la dialéctica viva de Lutero (no la dialéctica lógica), heredada de san Pablo y de san Agustín ${ }^{43}$, ni tampoco el carácter experiencial de su teología para explicar la justificación por la fe fiducial o fe, esperanza y caridad, que ha sido ya objeto de muchos estudios a veces bastante opuestos entre sí ${ }^{44}$. Es más importante ir a la raíz de toda su doctrina, es decir, a la relación entre la gracia y la libertad humana, no sea que todos los laberintos y las contradicciones que muchos encuentran en él procedan más bien de tratar de interpretarlo con categorías aristotélicas, estáticas y fisicistas, tan extrañas generalmente en él como lo son en las obras de san Agustín.

Es obvio que Lutero dio mucha importancia al pecado de origen y a sus consecuencias, como era entonces común, porque dominaba en todas partes el positivismo bíblico y eran del todo desconocidos los métodos de la hermenéutica actual. También es cierto que Lutero no comprendió ciertos aspectos de la doctrina de san Agustín sobre el pecado de origen y sobre la imagen divina del hombre y su reforma por la gracia, precisamente porque hay una clara evolución en san Agustín ${ }^{45}$. Sin embargo, sí comprendió muy bien que el punto radical de la antropología y de la espiritualidad cristiana es, además del Credo, poner a salvo la gratuidad de la gracia de Dios por Cristo crucificado (theologia crucis) frente a toda forma de neopelagianismo escolástico que, según él, hacía también depender a Dios de las decisiones del hombre destruyendo esa gratuidad del amor salvador divino. Así se lo dice, como una alabanza a su ingenio, a Erasmo, el cual, según Lutero, era un gran humanista pero muy poco evangélico, cuando escribe una de sus obras predilectas, De servo arbitrio (a. 1525) en respuesta al escrito de Erasmo contra su librito «sobre la libertad cristiana» a León X, titulado De libero arbitrio diatribe (a. 1524): La cuestión esencial no es el papado, ni el purgatorio ni las indulgencias; éstas son verdaderas bagatelas comparadas con el problema de la gracia y el libre albedrío ${ }^{46}$.

43. E. DE NEGRI, La teología di Lutero. Rivelazione e dialettica, Firenze 1967.

44. Visión panorámica en J. WICKS, Justification and Faith in Luther's Theology: Theological Studies 44 (1983) 3-29.

45. A. Turrado, Dios en el hombre, BAC, 1971, 288-317. Si bien en ese estudio no analicé aún el influjo de la mentalidad bíblica de Lutero en la relación entre la gracia y la libertad. Para la evolución de la doctrina de san Agustín sobre la imagen divina del hombre (261-287).

46. Lutero alaba el ingenio de Erasmo, y él sólo se gloría de ser cristiano. Y le dice: «Deinde et hoc in te vehementer laudo et praedico, quod solus prae omnibus rem ipsam es agressus, hoc est, summam causae, nec me fatigaris alienis illis causis de Papatu, purgatorio, indulgentiis ac si- 
Se van a enfrentar dos mentalidades con un substrato cultural en esto completamente distinto, a pesar de que también Erasmo había proclamado su rechazo de la teología escolástica. No se trata únicamente de una noción diversa de Dios y del hombre, según dice el teólogo luterano H. Bornkamm ${ }^{47}$, sino también de unos presupuestos filosóficos y lingüísticos muy diferentes.

Frente a la filosofía helénica, y en especial la aristotélica, con sus concursos, impulsos y fisicismos «en el orden natural y sobrenatural», y frente a la psicología racional aristotélica con sus tres potencias realmente distintas entre sí y realmente distintas del alma, y a su ética natural, Lutero combate a Erasmo desde el ámbito de la mentalidad bíblica, dinámica y funcional (ser-enacción), y desde una teología de manifestación o epifanía, de tal modo que lo que no se manifiesta actuando es como si no existiera. En la perspectiva de la gracia y el libre albedrío, éste no puede actuar por sí mismo sin la ayuda de Dios en orden a la salvación y, por lo mismo, es como si no existiera y dinámicamente no existe de hecho. En cambio, bajo el aspecto negativo, actúa con tanto más vigor para decir NO a Dios y a su atracción en Cristo, siendo el pecado, como dice san Pablo, san Juan y repite con frecuencia san Agustín, lo único que puede hacer por sí mismo al hombre.

A este panorama es preciso añadir un influjo evidente en Lutero del mal llamado nominalismo de Guillermo de Ockham, pero en cuanto era una filosofía del lenguaje. Porque, como dice un especialista moderno, el nominalismo no era una epistemología que negase el conocimiento de lo universal para centrarse únicamente en el conocimiento de lo concreto y experimentable, como si los nombres (de ahí nominalismo) pudiesen cambiarse convencionalmente para designar unas cosas u otras (lenguaje de puro convencionalismo) y no expresaran una realidad objetiva anterior al lenguaje y especial ${ }^{48}$. Por eso, a pesar de sus críticas posteriores a G. Biel, en cuya obra solían estudiar entonces la doctrina de Ockham ${ }^{49}$, esa filosofía del lenguaje lleva a Lutero a una concepción pura y utópica de la libertad o libre albedrío, semejante a la no-

milibus nugis potius quam causis, in quibus me hactenus omnes fere venati sunt frustra. Unus tu et solus cardinem rerum vidisti et ipsum iugulum petisti pro quo ex animo tibi gratias ago" (De servo arbitrio: W. 18,786).

47. H. BoRnKamm, Das Jahrhundert der Reformation (Insel Taschenbuch), Frankfurt a.M. 1983; «Erasmus und Luther» (46-71).

La mayor parte de los historiadores no comprenden la gravedad del problema de la gratuidad de la gracia y sus consecuencias secularizantes, en el humanismo de Erasmo. Cfr. LEFEBvRE, Erasmo, la contrarreforma y el espíritu moderno, Barcelona 1985, 75ss.; Cfr. I. de la VIUDA, De servo arbitrio: Réplica de Lutero a Erasmo, en «Rev. Agustin.» 24(1983)483-533.

48. T. de ANDREs, El nominalismo de Guillermo de Ockham como filosofía del lenguaje, 1967.

49. G. BIEL, Collectorium sive epithoma in IV libros Sententiarum (comentarios de Ockham a los cuatro libros de las sentencias de Pedro Lombardo, resumidos), Tübingen 1501. 
ción utópica de san Agustín contra los pelagianos, poniendo únicamente en Dios la noción pura del libre albedrío: como la posibilidad de querer y hacer solamente el bien. Cuando falta esa posibilidad, el libre albedrío necesitado de la ayuda de la gracia divina para actuar en orden a la salvación es como si no existiera: por sí solo es ineficaz y, por lo tanto, no se manifiesta (ser-enacción) en ese orden de la salvación, sino únicamente en su opuesto, es decir, en la posibilidad de decir no a Dios, de pecar, que es exclusiva suya.

Éste es el tema constante en su obra preferida De servo arbitrio contra la Diatribe de Erasmo: Lutero, con su mentalidad dinámica bíblica, ve que Erasmo mezcla muy mal el esencialismo griego (es o no es) y el dinamismo bíblico (ser-en-acción) cuando dice que el libre albedrío es una fuerza minúscula e ineficaz por sí (vim modiculam et inefficacem), y le objeta: $\mathrm{Y}_{\text {¿qué es una fuerza }}$ o virtud ineficaz, sino ninguna fuerza: Quid est vis inefficax, nisi plane nulla vis? ${ }^{50}$. Por eso el concepto puro de libre albedrío sólo corresponde a Dios, que hace cuanto quiere en el cielo y en la tierra. Ciñéndose a la noción entonces corriente de libertad, Lutero le dice a Erasmo que el pueblo entiende por libertad o libre albedrío la libertad de elección, es decir, «la fuerza o virtud (vis) que puede orientarse en un sentido o en otro, sin tener que ceder o estar sometida a nadie: vis quae libere possit in utrunque se vertere, neque ea vis ulli caedat vel subiecta sit» ${ }^{51}$. Y si el pueblo supiera que aplicamos ese título a esa fuerza ineficaz por sí misma, cautiva de Satanás, nos apedrearía como a engañadores y creadores de vanas ilusiones. Ésa fue precisamente la ilusión de los pelagianos, que hablaban del sentido y de la realidad del libre albedrío que nunca tuvimos (y de hecho ellos decían también que todos eran pecadores). Eso es un absurdo, una ironía y una contradicción, que suena de este modo: el hombre tiene albedrío, pero sólo si Dios le presta el suyo ${ }^{52}$. Así que, concluye Lutero, hay que usar palabras propias y puras, sobrias y, como dice san Pablo (Tit 2,8), sanas e irreprensibles ${ }^{53}$.

Erasmo había citado a su modo muchos concilios, papas y teólogos para defender el libre albedrío en el orden de la salvación, omitiendo curiosamente a san Agustín (habiendo sido él canónigo regular de san Agustín y editor de alguna de sus obras). Y Lutero, después de recordarle que la única fuente de su

50. De servo arb., W. 18,636; «liberi arbitrii vim modiculam et talem facis, quae citra gratiam Dei, prorsus sit inefficax» (Ib., 635). 662).

51. De servo arb.: W. 18,636; «liberum arbitrium nemini nisi soli Deo convenire» (Ib.,

52. Ib., W. 18,637: «Ita et hic sonat: Homo est liberi arbitrii, ita sane, si Deus illi suum concederet».

53. Ib., W. 18,638 . 
teología era la sagrada Escritura, le recuerda: «Pero Agustín, a quien tú omites, es todo mío» ${ }^{54}$.

El resto de la polémica con Erasmo al analizar ampliamente los textos bíblicos que éste le cita en su contra, puede reducirse a esta idea muy justa de Lutero dentro de esa mentalidad dinámica (ser-en-acción): Todos esos textos indican que la Escritura nos enseña lo que debemos hacer, pero no en absoluto que lo podamos hacer sin la ayuda de la gracia. Por lo tanto, le dice, abandona todos esos «tropos» aristotélicos y su ética naturalista, y atiende únicamente a la cruz de Cristo de donde nos viene la salvación ${ }^{55}$. Situados aquí en dos mundos diversos, Lutero en la mentalidad dinámica bíblica (ser-en-acción) de modo que lo que no puede actuar en un orden de cosas es como si no existiera, y Erasmo en la mentalidad esencialista griega (es o no es), no pueden entenderse en modo alguno. Lutero descubre a Erasmo sus contradicciones continuas bajo su punto de vista, y Erasmo ataca a Lutero como destructor de la tradición (de la cultura griega, debería decir). Lutero aconseja a Erasmo que se dedique a las letras y a los idiomas, que en eso le ha sido a él mismo de gran utilidad por sus ediciones de la Sagrada Escritura y de los santos Padres; sin embargo, Dios no le ha dado aún el don de profundizar en la cuestión de la gracia, que es la causa presente: Huic nostrae causae ut par esses, nondum voluit nec dedit Deus ${ }^{56}$. A partir de entonces ambos comienzan a enviarse cartas con acusaciones durísimas, cuyo lenguaje mismo resulta en extremo violento, hasta que rompen totalmente su correspondencia ${ }^{57}$.

Esta visión del libre albedrío en Lutero quedaría truncada si no analizára-

54. Quanquam et Augustinus, quem tu praeteris, meus totus est (De servo arb., W. $18,640)$. Más adelante, hacia el 1531, parece que el mismo Lutero adopta algunas reservas sobre la doctrina de san Agustín en torno a la justicia por la fe, y lo mismo hace Melanchton. Tal vez no comprendieron que san Agustín habla con preferencia de la caridad y que la fe fiducial de que hablan ellos implica también la esperanza y la caridad, si bien prefieren decir que la caridad es fruto de la fe. Cfr. P. Bergauer, Der Jakobusbrief bei Augustinus, Wien 1962, 88ss.; A. Turrado, Dios en el hombre, 288ss.

55. De servo arb.: W. 18,706ss. «Verba legis dicunt: Tu debes, non dicunt: Tu potes. A debere ad posse non valet consequentia» (Disputatio de homine, a. 1536, W. 39 I, 180); In Ep. S. Pauli ad Gal. Comment., a. 1531-1535, W. 40 II, 78-83.

56. De servo arb., W. 18,786. Lutero dice a su amigo Spalatin, cuando estaba escribiendo el De servo arbitrio, que Erasmo no ha dicho nada razonable en su Diatribe: «Ego iam totus in Erasmo et libero arbitrio versor, daboque operam, ut nihil patiar illum recte dixisse, sicut vere nihil dixit recte» (Carta a Spalatin, 28 sept. 1525, W. Brw. 3,583).

57. Cuando Lutero conoce la respuesta de Erasmo (Hyperaspistes I) a su De servo arbitrio le llama en una carta a Spalatin "víbora y animal cargado de soberbia» (gloria istud animal vanissimum) (27-III-1527): W. Brw. 4,41-42). Ib., 70; carta a Jonás: Ib., 4,268. Por su parte Erasmo contesta a una carta de Lutero, en la que éste trata de justificarse por su apasionamiento en el $D e$ servo arbitrio, y lo tacha de «ingenio arroganti, procaci, seditioso, totum orbem exitiabili dissidio concutis» (desde Basilea, 11-IV-1526: W. Brw. 4,46-48). Y otras muchas que recoge la introducción al De servo arbitrio en W. 18,551-596. 
mos brevemente la cuestión inseparable de la anterior, es decir, la posibilidad exclusiva del hombre de decir No a Dios o al pecado. Sólo si se tiene en cuenta esa mentalidad dinámica bíblica de Lutero podrán comprenderse las expresiones extremas acerca del libre albedrío en el orden de la salvación ya desde sus primeros escritos, tan adulteradas por otra parte en los libros de texto católicos y en muchos historiadores. Es bien conocida la tesis de Lutero en su respuesta a las condenas de la Bula exsurge Domine de León X (a. 1520), cuando dice: «El libre albedrío después del pecado de Adán es una cosa de puro nombre o título (res est de solo titulo) y por sí solo no puede más que pecar» ${ }^{58}$; expresión tomada de las obras antipelagianas de san Agustín. Los que han dado a esas expresiones un sentido esencialista griego (es $o$ no es), no pueden en modo alguno comprender que ese mismo «no-existente libre albedrío» en el orden de la salvación pueda decir «no» a la llamada de Dios, que Lutero hable con insistencia de la necesidad de la oración por el mandato y las promesas que Dios ha hecho, y de la necesidad de nuestra cooperación en ciertos ministerios para coadyuvar a la acción interior (intus) de Dios en el alma; de tal modo que, citando a san Àgustín de memoria, llegue a decir: el que te hizo sin ti, no quiere salvarte sin $t i{ }^{59}$. Esa es la voluntad de Dios tal como aparece en la Sagrada Escritura (ordinata Dei voluntas), y quiere que oremos y quiere dar a los que oran el Espíritu Santo y todo lo necesario ${ }^{60}$.

Dentro de esa mentalidad bíblica, dinámica, dialéctica viva y relacional, que quiere que Dios sea siempre Dios y que nosotros seamos sus criaturas e hijos, y que contempla al hombre como un dinamismo unitario con diversos aspectos, - por eso habla Lutero de la unión indisoluble de las virtudes teologales ${ }^{61}$-, él insiste desde el principio, citando a san Pablo y a san Agus-

58. Art. 36: Liberum arbitrium post peccatum res est de solo titulo, et dum facit, quod in se est, peccat mortaliter. Lutero lo confirma con un texto de san Agustín, De spir. et litt. III: «Liberum arbitrium sine gratia non valet nisi ad peccandum». Y añade: «Est hoc esse liberum, non posse nisi peccare? S. Juan nos dice: Sin mí no podéis hacer nada, y con náda no puede uno prepararse para la gracia: «Mira praeparatio quae per nihil fit» (Assertio omnium articulorum M. Lutheri per Bullam Leonis... a. 1520: W. 7,142. Lo mismo se encuentra ya en la Disputatio Heidelbergiae habita 1518. W. 1,359-360, citando el C. Jul.II de san Agustín; De servo arb., W. 18,670.

59. El texto auténtico de san Agustín dice «qui ergo fecit te sine te, non te iustificat sine te» (S. 169,11,13). Vorlesungen über 1. Mose, 1535-45, W. 43,81: «Dat quidem Deus omnia ex gratuita misericordia, et tamen vul orari».

60. Haec enim ordinata Dei voluntas est, quod vult orari et orantibus dare Spiritum Sanctum et omnia necessaria (Ib., W. 43,81-84, 118,136, 396-399; Tractatus de libertate christiana, a. 1520, W. 7,73; con frecuencia en ambos Catecismos: W. 30 I, 125-238 (cat. breve), y 346-402 (cat. grande).

61. La fe y la esperanza, aunque sean aspectos distintos de nuestra justicia en proceso y de nuestro dinamismo espiritual, no se pueden separar: «Hac in re valde sudaverunt Sophistae, sed nihil certe ostendere potuerunt... Tantam enim cognationem inter se habent fides et spes, ut haec ab illa divelli non possit» (In Ep. ad Gal. Comment., 1531-1535, W. 40 II, 25). La caridad, dirá 
tín, en que lo único exclusivamente nuestro es la desobediencia a la voz de Dios, el no a su llamada, el pecado. Pero ésa no es la libertad verdadera con respecto al Evangelio y a la salvación. Eso es más bien una esclavitud, según san Juan y san Pablo; es una negación de la libertad, una esclavitud del pecado. Por eso añade Lutero que, «a pesar de la dificultad de los germanos para expresarse en latín, pongo a Dios por testigo de que todas las opiniones que cita Erasmo sobre el libre albedrío coinciden en que éste sólo puede querer y elegir el bien con la ayuda de la gracia: Así que, si después del pecado, el libre albedrío perdió la libertad y está bajo la servidumbre del pecado y no puede querer ningún bien, yo sólo puedo deducir de estas palabras que el libre albedrío es una palabra vacía cuyo contenido se perdió (inanem voculam, cuius res amissa sit). Y si se pierde la libertad, mi gramática la llama «ninguna libertad»; de modo que atribuir la libertad a lo que no tiene libertad es atribuirle un término vacío. "Que me corrija el que pueda» ${ }^{62}$. Se refiere, como siempre, al orden de la salvación. En cambio, con su mentalidad dinámica y la consiguiente teología de manifestción, no duda en decir a Erasmo que la voluntad impía sí es algo, y no una pura nada, en orden al pecado ${ }^{63}$.

Ante la definición de libertad de Erasmo y de los escolásticos «como una vuerza (vis) que puede elegir entre dos cosas, en este caso, entre el bien y el mal, entre pecar o no pecar» ${ }^{64}$, Lutero le dice que su definición es aún mucho peor que la de los pelagianos, también de raíz aristotélica; que no es posible llamar libre al esclavo, y que hubiera sido mejor haberlo llamado arbitrio cambiable o mudable (vertibile arbitrium vel mutabile arbitrium). Los sofistas

muchas veces, es fruto inseparable de la fe, del mismo modo que las buenas obras brotan ya necesariamente de esa fe. Con su mentalidad existencial, la libertad es contemplada por Lutero como gracia de Dios que libera en orden a la fe, y por eso como libertad que vive de la fe. Cfr. G. EBELING, Luther-studien. Bd. I. Tübingen 1971, 324; «Frei aus Glauben» (308-324).

62. De servo arb., W. 18,670s., 709-711, 735-738, 768,774ss. Reconocerse débil y necesitado de la ayuda de Dios y pedirla, ése es el camino justo: «Est quidem donum gratuitum, sed multi id donum accipere nolunt; of ertur illis donum, sed ipsi id contemnunt. In recipientibus est vitium, non in Deo, qui ultro et gratis omnia offert, ut perstet sententia: Non est colentis et currentis, sed miserentis Dei (Rom 9,6) «(Disputatio de veste nuptiali, a. 1537, W. 39 I, 310); Enarrat. Ps. 51, a. 1532-38, W. 40 II, 438; Vorlesungen über 1. Mose, W. 42,290; «concludimus ergo universaliter. Quod homo sine Spiritu sancto et sine gratia nihil potest facere quam peccare et ita progreditur in infinitum, de peccato in peccatum». (Ib., W, 43,176-177). Por eso creo que esta perspectiva hermenéutica de la cultura y dialéctica semitas y el influjo de san Agustín da una visión muy distinta de Lutero en su respuesta a Erasmo, a no ser que sigamos midiéndolotodo por las categorías aristotélicas, como hace G. Chantraine, Erasme et Luther libre et serf arbitre, Paris-Namur 1981.

63. Nam hoc agimus, quod liberum arbitrium sit nihil, id est inutile per sese, ut tu exponis coram Deo, nam de hoc genere essendi loquimur, non ignari, quod voluntas impia sit aliquid et non merum nihil (De servo arb., W. 18,751).

64. Erasmo define el libre albedrío como «vim humanae voluntatis, qua se possit homo applicare ad ea, quae perducunt ad aeternam salutem, aut ab iisdem avertere» (De servo arb., W. $18,661)$. 
escolásticos han abusado de la expresión agustiniana «libre albedrío» en contra de la gratuidad de la gracia y de la atracción del Espíritu Santo. Así que esa fuerza o capacidad de elegir (vis eligendi, conatus) de Erasmo con respecto al Evangelio y sin la gracia es mucho más destructora que la de los pelagianos y los sofistas ${ }^{65}$. Está además llena de contradicciones, «porque, si en tu misma opinión el libre albedrío perdió la libertad después del pecado y sólo puede por sí servir al pecado, y sin la gracia no puede querer el bien, no debes llamarlo ya libre albedrío» ${ }^{66}$.

Se trata, pues, de una noción diversa de libertad según qué mentalidad se tenga, la dinámica evangélica de Lutero o la esencialista y estoica de Erasmo en conformidad con la ética de Aristóteles y de los estoicos. Para Lutero, según hemos visto, todos los textos bíblicos que le opone Erasmo no indican más que esto: que nos enseñan lo que debemos hacer, pero no que podamos hacerlo sin la ayuda de la gracia. Acudir a la diversidad de las consecuencias del pecado de origen que hay en esas dos mentalidades no resuelve en absoluto el fondo de la cuestión. Es obvio que Lutero - y en esto ya no comprendió bien a san Agustín-, habla de que por ese pecado el hombre perdió sus cualidades naturales y su imagen divina, es decir el libre albedrío y la capacidad de relación con èl Dios de la misericordia sin la gracia; y es cierto también que los escolásticos, y más tarde Trento nos dirán que por ese pecado el hombre quedó herido en las propiedades naturales (vulneratus in naturalibus) y menguado en su ejercicio, pero no privado de las mismas. Pero esta postura diversa queda dentro de la explicación mítica del origen del mal y de nuestra realidad, mientras que la explicación de eśa misma realidad con respecto a la conversión, justificación y salvación entra ya de lleno en el ámbio de la gratuidad del amor $y$ de la ayuda de Dios. Aun superando la mentalidad tribal en que todos se movían debido a su positivismo bíblico y a su interpretación histórica del Génesis (cc. 2-3) para situarnos con el Vat. II en el marco de la teología de la creación, según indicamos antes, pienso que la cuestión no es tratar de contrapo-

65. De servo arb., W. 18,662ss. Si esa fuerza (vis) tiene la posibilidad «legem et Evangelium velle, peccatum nolle et morten velle, divinae virtutis est solius, ut Paulus non uno loco dicit. Proinde nemo post Pelagianos rectius de libero arbitrio scripsit, quam Erasmus» (Ib., 664).

66. De servo arb., W. 18,668. Según Lutero, es mucho mejor la definición de Pedro Lombardo, siguiendo a san Agustín: «planeque cum Augustino sentit liberum arbitrium suapte vi non posse nisi cadere nec valere nisi ad peccandum (De spir. et litt. 3,5, PL 44,203). Unde et servum potius quam liberum arbitrium vocat Augustinus libro 2 contra Julianum (II, 8,23, PL 44,689); mientras que Erasmo le atribuye tanta fuerza «quod suapte sine gratia vi et sese applicare possit ad bonum et sese avertere a bono». Así que los ciegos sofistas deberían estar conmigo y luchar cotra tu libelo (Ib., 665). No todos parecen captar la importancia decisiva de esa diferente noción de «verdadera libertad» en Erasmo y en Lutero: cfr. Luther und Erasmus: Free Will and Salvation, Ed. E.G. Rupp und D. Watson, Philadelphia 1969, 143. 
ner la doctrina de Lutero y la de Trento ${ }^{67}$, ni siquiera en considerarlas como dos caminos diversos para exponer la justificación del hombre, como hace O.H. Pesch.; sino que está en atender a esa diferencia entre la mentalidad dinámica de la Biblia en Lutero y a la mentalidad esencialista y fisicista de Erasmo, de los escolásticos y de Trento, basada en las categorías cosmológicas de Aristóteles. De este modo se ve mejor la tragedia del s. XVI, puesto que, además de un lenguaje en extremo violento por ambas partes, la incomprensión mutua se debió ante todo a la falta de un diálogo reposado y serio y a no haber invitado a Lutero al concilio de Trento para que explicase detenidamente su doctrina ciertamente bíblica y agustiniana, según lo había pedido con insistencia él mismo, con el deseo de llevar a cabo la reforma desde dentro de la Iglesia. Hoy día es ésta una tesis admitida por la gran mayoría de los teólogos católicos, me refiero a los deseos de Lutero de hacer una reforma intraeclesial. Pero entonces no fue posible pasar de una teología de cosas sagradas a una teología de relaciones interpersonales como la de san Agustín y Lutero.

Es triste comprobar que los Padres de Trento no pudieron tampoco comprender ya el sentido bíblico de la fe fiducial de Lutero. Para él esa fe es la pistis del Nuevo Testamento, inseparablemente fe, esperanza en las promesas divinas y caridad como fruto de la fé. Por eso para él «la fe es una cosa viva y fuerte, y no un pensamiento ocioso» ${ }^{68}$. En cambio, para los escolásticos y Trento, la fe era la aceptación de las verdades reveladas sin más, con todo lo que esto trae de dualismo para separar en el mensaje de Cristo la fe y el compromiso, la verdad y la moral, la teología y la espiritualidad. Enfrascados en sus fisicismos sobre la gracia como «una segunda naturaleza» y en poner una realidad subyacente a todos los términos que emplean, no pueden comprender

67. Cfr. J. MARTín PARMA, Gnadenlehre von der Reformation bis zur Gegenwart, en «Handbuch der Dogmengeschichte», hrsg. von M. Schmaus, A. Grillmeier, L. Scheffczyk u.M. Seybold, Bd. III, Fasz. 5b, Freiburg-Basel-Wien 1980, 7ss., 21.

El mismo Jerónimo Seripando, legado papal enTrento y antiguo General de la Orden Agustiniana, si bien había defendido la inclusión de la duplex iustitia (justicia interior y confianza total en Cristo) en el decreto de la justificación, ya no logra entender la doctrina de Lutero sobre la justificación por la fe, la gracia como atracción y la verdadera libertad. Cfr. A. MARRANZZINI, Dibattito Lutero-Seripando su «Giustizia e Libertd» del Cristiano, Brescia 1982; O.E. PESCH; Hinführung zu Luther, 154ss.; J. AlfaRo, Certitude l'espérance et «certitude de la grâce». Contributión au dialogue oecuménique: NRTh 104(1972) 3-42; ver p. 29: La «vana fiducia» rechazada por Trento (D.- Sch. 1533) difiere radicalmente de la confianza enseñada por Lutero, que se opone siempre a cualquier seguridad que el hombre pueda encontrar en sus propios actos.

68. Vorlesungen über 1. Mose, W. 42,452: «Est enim fides res vivax et potens: non est otiosa cogitatio». Los sofistas que, con Aristóteles, presentan a un Dios filosófico y metafísico separado de sus criaturas: «Sic illi amplius nihil de fide norunt, existimant esse otiosam cogitationem, aut notitiam tantum, qualis in daemonibus est. Nesciunt fidem esse, credere et assentiri Deo promittenti et iuranti... Vera auten fides sic statuit: Deus mihi Deus quia mihi loquitur, mihi remittit peccata, non irascitur mihi: sicut promittit ego sum Dominus Deus tuus» (Ib., W. 43,243). 
tampoco el sentido dinámico y experiencial que Lutero da al pecado y a la justificación, ni mucho menos la noción dinámica y psicológica de la gracia que Lutero toma de san Agustín, atendiendo al único modo como actúan los hombres en su vida real, es decir, atraídos por el deseo de placer en sentido amplio: trahit sua quemque voluptas (In Jn Tr. 26,4, tomado de Virgilio, Egloga 2). Es la tesis común de la psicología moderna, atenta siempre a la experiencia humana.

\section{- La gracia como «atracción deleitosa» por el Espíritu Santo}

Es impresionante la insistencia de Lutero en concebir la gracia divina como inseparable de las virtudes teologales y como una atracción, suavidad y tendencia (pronitas) del Espíritu Santo. Lutero la contempla como una especie de enamoramiento de la voluntad de Dios, tal como se nos manifiesta en el Cristo de la Cruz. No hay, pues, en ello coacción de ningún tipo, como no la hay en el enamoramiento o en la búsqueda del placer. Pero esa gracia divina o atracción hace que hagamos por amor la voluntad de Dios infalible pero libremente: Necessario vero dico, non coacte ${ }^{69}$. Es el comienzo en actos concretos del ideal o utopía de la libertad evangélica de llegar a poder elegir únicamente el bien como el Padre celestial (Mt 5,48).

Ya en su obra De servo arbitrio (1525) usa desde el principio esas expresiones de cuño claramente paulino y agustiniano. El conocido axioma de san Agustín: Dios hace que hagamos (facit ut faciamus) deleitosamente y con placer su voluntad, y en eso consiste la libertad verdadera, será la clave de Lutero para combatir la definición estoica de libertad que Erasmo se empeña en mantener en el orden de la gracia (poder elegir entre el bien y el mal). Lutero, desde su mentalidad dinámica y experiencial, le replica que, a pesar de todo, existe en el hombre la voluntad, porque no hay coacción. Actuamos queriendo con placer (volentes et lubentes), puesto que la coacción es en cierto modo una no-voluntad (noluntas). Recordando la tesis dialéctica de su opúsculo Sobre la libertad cristiana, le dice a Erasmo que por el Espíritu de Dios nos hacemos siervos y cautivos suyos, y ésa es la libertad suprema (quae tamen regia libertas est); de ese modo hacemos y queremos con placer todo lo que Dios quiere. Y lo mismo cabe decir en sentido opuesto, si nuestra voluntad está invadida por Satán, y encuentra su placer en el mal ${ }^{70}$. Erasmo, con su definición estoi-

69. De servo arb., W. 18,634.

70. Si Deus in nobis operatur, mutata et blande assibilata per Spiritum Dei voluntas iterum mera lubentia et pronitate ac sponte sua vult et facit, non coacte, ut nullis contrariis mutari in aliud possit, ne portis quidem inferi vinci aut cogi, sed pergit volendo et lubendo et amando bonum, sicut antea voluit et lubuit et amavit malum. Quod iterum probat experientia quam invicti et constantes sint viri sancti, dum per vim ad alia coguntur, ut magis inde invitentur ad volendum, sicut ignis a vento magis inflammatur quam extinguitur, ut nec hic sit ulla libertas vel liberum ar- 
ca de libertad y en este caso con su aristotelismo esencialista (es o no es) ya no pued̦e comprender ni a san Agustín ni a Lutero, y se empeña en seguir hablando de una voluntad oscurecida, no extinguida del todo, pero de hecho ineficaz por sí misma para las cosas honestas, mientras que Lutero no ve más libertad en ejercicio que la de decir no a Dios, es decir, la de pecar por sí sola ${ }^{71}$.

Tampoco los pelagianos, y más tarde Bayo y los jansenistas, pudieron comprender la célebre delectación vencedora (delectatio victrix) de san Agustín referida a la gracia divina por la caridad del Espíritu Santo, porque transportaban esas expresiones a las categorías aristotélicas de libertad y a la exigencia jurídica del hombre con respecto a la gracia divina que él necesita para lograr cumplir el deseo innato de la felicidad perfecta o visión beatífica ${ }^{72}$.

Como era de esperar, Lutero se enfrenta a Erasmo con más agrado al analizar los textos de san Juan y de san Pablo que él cita en su Diatribe. Se trata, dice Lutero, de afirmaciones universales sobre la gratuidad de la gracia, que no admiten fácilmente escapatoria. Y aquí aparece la diferencia que hay para Lutero entre ir en pos de (seguir) y dejarse llevar sin oponerse o decir no. Erasmo cita una imagen muy querida para san Agustín - aunque sin citarlo expresamente, le dice Lutero-, en la que trata de descubrir esa fuerza o conato (vis, conatus) del libre albedrío bajo la gracia. Al comentar el texto de san Juan: Nadie viene a mí, si mi Padre no lo trajere $(6,44)$, Erasmo comenta la imagen de san Agustín: Dios nos atrae de un modo semejante a como nosotros atraemos a la oveja, es decir, mostrándole un ramo verde; y de ese mismo modo, dice Erasmo, hay en nosotros una fuerza o virtud para seguir la atracción de Dios. Lutero le contesta con energía que ese seguimiento se debe únicamente a la atracción interior (intus) del Padre por la donación de su Espíritu, como una iluminación y un rapto dulcísimo hacia Cristo en una confianza total para dejarse llevar ${ }^{73}$. No voy a recordar aquí el posible influjo en esa postura de la mística alemana de entonces, porque se trata evidentemente para Lutero de una de las verdades fundamentales del Nuevo Testamento, de vida o muerte para la Iglesia.

bitrium alio sese vertendi aut aliud volendi, donec durat Spiritus et gratia Dei in homine» (De servo arb, W. 18,634-635).

71. De servo arb., W. 18,635. En notas los textos de Erasmo de la Diatribe y del Hyperaspistes $I$.

72. A. Turrado, La antropología de san Agustín, 108ss., 125ss.

73. Esa atracción se puede aplicar muy bien a las ovejas que ya conocen a Dios, su pastor: «hi Spiritu viventes et moti sequuntur, quorsumque Deus voluerit et quicquid ostenderit. Impius vero non venit etiam audito verbo, nisi intus trahat doceatque Pater, quod facit largiendo Spiritum. Ibi alius tractus est, quam is qui foris fit; ibi ostenditur Christus per illuminationem Spiritus, qua rapitur homo ad Christum dulcissimo raptu et patitur loquentem doctorem et trahentem Deum potius quam ipse quaerat et currat» (De servo arb., W. 18,781-782). 
Lutero propone ya esta misma doctrina en su comentario a la Carta a los Romanos (1515-16), siguiendo a san Agustín, de tal modo que la delectación en la ley de Dios nos viene por la caridad o gracia de Dios que difunde en nuestros corazones el Espíritu Santo que nos ha sido dado ${ }^{74}$. Y en su Catecismo Grande (1529), al exponer el Credo y su profesión de fe en el Espíritu Santo nos dice que somos santificados por los dones del Espíritu y que él nos enseña y dona la fe para cumplir los diez mandamientos de Dios con gusto o placer $y$ amor: kriegen wir Lust und Liebe zu allen Geboten Gottes ${ }^{75}$. Esta noción de la gracia divina como atracción deleitosa, como placer y amor en el bien, de raíz tan profundamente joanea, paulina y por supuesto agustiniana, no debe olvidarse nunca al tratar de comprender la doctrina de la justificación de Lutero.

Las consecuencias de esa mentalidad dinámica, dialéctica y utópica de Lutero son múltiples y muy difíciles de comprender para un escolástico.

Baste recordar que su oposición a hablar del mérito de las buenas obras parte en él de esa gratuidad total de la gracia divina, como la caridad brota espontáneamente del don de la fe y el fruto bueno brota del árbol bueno, según dice el Evangelio. Pero el mérito es un término jurídico que no le agrada, porque la confianza total en las promesas de Cristo y la utopía del amor no sabe de méritos sino de amor; de tal modo que san Agustín repetía de continuo que «cuando Dios corona nuestros méritos, corona de hecho sus dones». Y por lo que se refiere a la tan traída y llevada doctrina de la predestinación, es curioso que tanto Lutero como san Agustín dan la impresión de tener una doctrina

74. Divi Pauli ad Rom., Ep., 1515-16, W. 56, 344-346: «ista delectatio est ex Spiritu sancto per charitatem, ut sepe dictum est, sine qua Impossibile est diligere legem et iustitiam; immo vehementius horret in lege quam sine lege, quia odit se scire debere, quod non cupit, immo contrarium cupit» (Ib, 346); Quaestio de viribus et voluntate hominis sine gratia disputata, 1516, W. 1,142151; Disputatio contra scholasticam theologiam, 517, W. 1,221-228; Disputatio de veste nuptiali, 1537, W. 39 I, 220-221; In Ep. S. Pauli ad Gal. Comment 1531-35, W. 40, II, 82ss. 97ss., 123ss.; Enarr. Ps. 51,1532-38, W. 40 II, 421 ss. Habitat ergo verus Spiritus in credentibus non tantum per dona, sed quoad substantiam suam. Neque enim sic dat dona sua, ut ipse alibi sit aut dormiat. Sed adest donis et creaturae suae conservando, gubernando, addendo robur... La gracia no es una cualidad oculta, como dicen los sofistas, sino la acción continua en nosotros del Espíritu Santo para que creamos en las promesas de Dios y hagamos lo que le place. «Spiritus enim est res viva, non mortua» (Ib., W. 40 II, 421-422).

Por eso no creo que sea muy objetivo el juicio de G. Chantraine sobre la doctrina de Lutero acerca del Espíritu Santo y su misión, como si no diera nada de sí mismo, sino únicamente revelando al Hijo y al Padre en su comunión. Esos textos indican todo lo contrario por su inhabitación activa, dinámica. Cfr. G. Chantraine, Erasme et Luther libre et serf arbitre, Paris-Namur $1981,455-456$. $49,52,56$.

75. Der Grosse und der Kleine katechis. hrsg. K. Aland und H. Kunst, Göttingen 1983, 
muy distinta en sus obras pastorales y en sus escritos más científicos y polémicos. Es evidente que ellos buscan ante todo salvaguardar la gratuidad de la gracia divina, y que cuando ponen su mirada en la eternidad y omnipotencia de Dios como sabiduría que todo lo contiene y abarca, da la impresión de que hay en ellos un determinismo irremediable; sin embargo, de hecho ellos están respetando el misterio de Dios y el misterio del hombre bajo su gracia, pero saben que lo importante para nuestra vida es cumplir el Evangelio y no cerrarnos al Espíritu tal como aparece en la historia de salvación o en el Dios revelado en Cristo ${ }^{76}$.

Por eso Lutero, no obstante la distinción entonces reinante de los nominalistas entre el Dios escondido y el Dios revelado y las correspondientes potencia absoluta y potencia ordenada, protesta solemnemente que él sólo tiene presente al Dios del perdón, al Dios manifestado en Jesucristo por la palabra, teniendo la confianza plena de que el que cree en él tiene la vida eterna ( $\mathrm{Jn}$ 3,36). Acordaos, pues, de respetar el misterio de Dios y de no plantear el problema de la «predestinación del Dios escondido». Esto lo he dicho ya en muchas de mis obras, pero habrá muchos que lo olvidarán y sacarán de mis escritos todo género de errores y delirios ${ }^{77}$. Y es mucho peor aún acudir al dios metafísico de Aristóteles y de los escolásticos, que quita el sano temor de Dios y su santo nombre ${ }^{78}$.

76. A. Turrado, La antropología de san Agustín, 134ss.

77. Es una llamada de atención de Lutero para el futuro que considero de gran importancia, y que la mayor parte de los teólogos católicos no han tenido en cuenta al interpretar su doctrina de la gracia y la predestinación. Después de exponer ampliamente esa distinción y la fe firme en la salvación o predestinación (la confianza total) dice: «Haec studiose et accurate sic monere et tradere volui. Quia post meam mortem multi meos libros proferent in medium, et inde omnis generis errores et deliria sua confirmabunt. Scripsi autem inter reliqua, esse omnia absoluta et necessaria: sed simul addidi, quod aspiciendum sit Deus revelatus, sicut in Psalmo canimus: Er heist Jesu Christ, der HERR Zebaoth, unde ist kein ander Gott (cfr. Ein feste Burg, estrofa 2), Jesus Christus est Dominus Zebaoth, Nec est alius Deus: et alias saepissime. Sed istos locos omnes transibunt, et eos tantum arripient de Deo abscondito. Vos igitur, qui nunc me auditis, memineritis me hoc docuisse, non esse inquirendum de praedestinatione Dei absconditi. Sed ea acquiscendum esse, quae revelatur per vocationem et per ministerium verbi. Ibi enim potes de fide et salute tua certus esse, ac dicere: Ego credo in filium Dei, qui dixit: Qui credit in filium, habet vitam aeternam (Jn 3,36). Ergo in eo non est damnatio aut ira, sed beneplacitum Dei Patris. Haec eadem autem alibi quoque in libris meis protestatus sum, et nun etiam viva voce trado. Ideo sum excusatus» (Vorlesungen über 1. Mose, W. 43,463); Ib., 239ss., 458-462, 547-551; De servo arb., W. 18,685ss.; Disputatio de veste nuptiali, W. 39 I, 287-289.

78. Dictata super Psalterium, W. 3,382,423,587; Asterisci Lutheri adversus obeliscos Eccii, 1518, W. 1,304; Vorlesungen über 1. Mose, W. 43,240ss. 
Quiero poner fin a estas páginas con una breve conclusión, que en modo alguno podrá resumir lo dicho en este estudio.

Son varios los puntos doctrinales por los que no pudieron entenderse Lutero, Erasmo y los escolásticos del concilio de Trento en lo tocante a la relación entre la gratuidad de la gracia y el libre albedrío, verdadera médula de la Reforma por sí y por sus consecuencias para la vida de la Iglesia. La «hermenéutica actual de las culturas», que implica el método histórico crítico, la filología y la semiótica, nos obligan a analizar cuidadosamente los códigos o tradiciones culturales de que se sirven esos métodos, en especial la semiótica para descubrir las relaciones de diferencia u oposición de los distintos términos del discurso (por emplear la terminología de Paul Ricoeur). Es una labor a veces costosa, pero del todo imprescindible para poder entender el lenguaje de los distintos autores y la raíz de sus posturas.

En este caso, el código fundamental es obviamente el filosófico o cultural: en san Agustín y en Lutero, la mentalidad dinámica, dialéctica y utópica de la Biblia, aunque con algunos matices diferentes en ellos, implica las ideas de ser-en-acción y la consiguiente teología de manifestación o epifanía; por eso lo que no puede actuar por sí mismo en el orden de la salvación es-comosi-no-fuera; Lutero lo expresa con frases contundentes (res de solo titulo), y san Agustín lo dirá con palabras de san Juan y de san Pablo, es decir, el libre albedrío es esclavo del pecado: lo que no puede manifestarse actuando en ese orden de salvación es como si no existiera. En cambio, Erasmo, los escolásticos y Trento, al igual que en el siglo $\mathrm{v}$ los pelagianos, tienen una mentalidad esencialista aristotélica (es o no es) y como el libre albedrío puede decir no a Dios por el pecado, no pueden menos de defender que el libre albedrío está ahí en el orden natural y en el orden sobrenatural, y que la libertad consiste propiamente, según dicen Aristóteles y los estoicos, «en poder elegir entre el bien y el mal, entre pecar y no pecar» (libertas contrarietatis). Esto es muy difícil de compaginar con la gratuidad de la gracia, por más que hablen de una libertad enferma y debilitada por el pecado de origen, de una fuerza y conato (vis, conatus), que necesita ser ayudada para poder actuar ( ifisicismo, en el que la acción es como un accidente con respecto al ser!). Esto no puede compaginarse fácilmente con la noción utópica y evangélica de libertad de san Agustín y Lutero, que la contemplan como «la posibilidad de querer y hacer sólo el bien», como el Padre celestial (Mt 5,48) por naturaleza y los bienaventurados por gracia. Como en su mentalidad dinámica y en el orden de la salvación la libertad o el libre albedrío no puede actuar sin la ayuda de la gracia (atracción, suavidad, placer, caridad del Espíritu Santo), dejándose llevar por esa atracción, para ellos es como si no existiera el libre albedrío, esclavo del pecado; en cambio, como puede oponerse a Dios y cerrarse en sí mismo por el pecado, sí existe el libre albedrío o la acción de la voluntad, que se manifiesta en esa esclavi- 
tud y desvarío; pero esa posibilidad es más bien una negación de la verdadera libertad, la evangélica.

Esa gracia divina como atracción, suavidad, placer y caridad del Espíritu es como un enamoramiento de la voluntad de Dios, un dejarse llevar por él (Spiritu Dei aguntur: Rom 8,14), para querer y hacer el bien sin fallo pero sin coacción (necessario, non coacte). Lutero habla incluso de "rapto dulcísimo» en su De servo arbitrio, que presupone una cierta pasividad mística en su teología de la justificación.

En cambio, la gracia de múltiples matices (preveniente, concomitante, habitual...) de que hablan Erasmo, los escolásticos y Trento es más bien un impulso o concurso «fisicista» en el marco del Dios Motor Inmóvil del aristotelismo, que mueve la fuerza o virtud y el esfuerzo (vis, conatus) del libre albedrío para que éste pueda ir en pos del bien; porque la libertad es para ellos, como para Aristóteles y los estoicos, lo que era para los pelagianos, es decir: «La posibilidad de elegir entre el bien y el mal, entre pecar y no pecar». Son dos mundos distintos, porque los que tengan la mentalidad dinámica y utópica del Evangelio nunca podrán comprender que se llame libertad a la posibilidad de pecar, de decir no a Dios.

Es cierto que en el ecumenismo actual ambas posturas se van reconciliando más y más, tratando de salvaguardar la gratuidad de la gracia divina y un cierto diálogo de salvación en el que Dios lleva siempre la iniciativa. Sin embargo, todos debemos superar la mentalidad tribal del pecado de origen y sus consecuencias y atender más a la realidad de los seres humanos en la magna historia de salvación que nos presenta la teología de la creación y la gran Alianza que en ella se inicia. Es lo que ha iniciado el Vaticano II, especialmente en su Constitución Gaudium et Spes (n. 12ss.), sin que por ello sufra mengua alguna el gran don de Dios a la humanidd, como signo o símbolo único y supremo de su amor, su Hijo Jesucristo. La gracia actúa en los hombres y mujeres de un modo pruriforme según la situación de las personas (Ib., 16-17,22), como indiqué al principio.

La doctrina de san Agustín y de Lutero sobre la gracia, en la línea evangélica y paulina (seguimiento del Modelo que atrae,: Jesucristo; fe fiducial, atracción, placer, suavidad, caridad del Espíritu Santo), y su atención a los estragos del egoísmo, pone más de relieve la necesidad de la oración humilde y de la confianza en Jesucristo; mientras que la mezcla extraevangélica de la ét $i$ ca natural de Aristóteles, que supone una naturaleza pura que no existe de hecho, y del fisicismo de la gracia que nos pone en movimiento, corre el peligro de orientar, en el ámbito cristiano, hacia una ascética y un ritualismo en exceso «autojusficadores» y por lo tanto a un proceso que lleva sin remedio hacia el secularismo o pérdida del sentido de la relación con Dios por la oración. 